\title{
Building adaptive capacity in a changing Arctic by use of technology
}

\author{
$\underline{\text { Jennifer I. Schmidt }}^{1}$, Vera H. Hausner ${ }^{2}$ and Christopher Monz $^{3}$
}

\begin{abstract}
Rapid Arctic warming, manifested as thawing permafrost, loss of coastal sea ice, sea level rise, and climate-related extreme events, is particularly challenging for Indigenous people relying on wild food to sustain their livelihood and culture. The adoption of new technologies could provide specific capabilities to confront vulnerabilities associated with fishing and hunting activities, but it could also accentuate existing vulnerabilities of the communities and undermine the generic (i.e., non-specific) adaptive capacities to respond to rapid environmental and socioeconomic changes. We investigated the role of technology for building capacity to respond to challenges posed by climate change in three remote communities in northwest Arctic Alaska. We refer to technology as tools used to change how people engage or relate to landscape or society. We interviewed 35 Inuit subsistence users and used Q-sort methodologies to examine their attitudes toward technology and climate change adaptation. Communication technologies and new ways of transport have allowed harvesters to travel faster and further, and $89 \%$ of the interviewees underscored the role of technology for enhancing the specific capacity to cope with extreme weather (77\%), foggy conditions (60\%), and environmental changes (89\%). Despite of the role technology plays in enhancing the capacity to respond to climate threats, just over half viewed technology as generally favorable for the community (54\%), although most admitted there are downsides (60\%), including higher financial costs (34\%), increased vulnerability $(23 \%)$, and time spent on maintenance $(9 \%)$. Our results underscore the need to focus on generic capacity when developing climate adaptation policies for Arctic Alaska to attend to both climatic and non-climatic stressors affecting the vulnerability of Indigenous communities.
\end{abstract}

Key Words: adaptive capacity; Alaska; climate change; resilience; social-ecological systems; subsistence; technology

\section{INTRODUCTION}

Rapid warming in the Arctic is particularly problematic for Indigenous people whose livelihood and culture are deeply connected to land, fresh water, and the sea through subsistence use (Wolfe 2004, Eicken et al. 2014, Ford et al. 2015, Fall 2016, Gray et al. 2018, AMAP 2021). Rising temperatures and precipitation have already profoundly changed the environment in which Indigenous people live (Gray et al. 2018, Box et al. 2019, IPCC 2019), and as a result, many communities have dealt with climate threats such as loss of sea ice, coastal and riverbank erosion, flooding, land slumping, rain-on-snow events, unreliable ice conditions on rivers and lakes, expansion of trees and shrubs, and increased weather unpredictability (Hinzman et al. 2005, IPCC 2014, Gray et al. 2018, Box et al. 2019, IPCC 2019, AMAP 2021). Environmental changes, such as those listed above, have implications that go well beyond availability of and access to food and water. They threaten the health and safety of residents, as well as Indigenous traditions and cultural identity that fundamentally rest upon contact with nature for sustenance (Cochran et al. 2013, Larsen and Fondahl 2014, ICC 2015, Loring and Gerlach 2015, Clark et al. 2016, Greaves 2016, Chatwood et al. 2017, Gray et al. 2018, Dankel et al. 2020, Griffin 2020, AMAP 2021). Understanding the vulnerability of Indigenous people, including their capacity to respond and adapt in the face of environmental changes, is therefore of utmost importance to Arctic residents and decision makers alike.

The ability of Indigenous people to respond to challenges posed by climate change and to reduce vulnerabilities associated with climate threats depends to a great extent on their local adaptive capacities. The Intergovernmental Panel on Climate Change (IPCC) defines adaptive capacity as "the ability of systems, institutions, humans, and organisms to adjust to climate change, moderate potential damages, take advantage of opportunities, or cope with the consequences" (IPCC 2014:1758). According to Eakin et al. (2014), adaptive capacity could be divided into two types of capabilities for responding to global changes: specific and generic. Generic capacity is focused on responding to the multiple stressors (climate and non-climatic) that generate structural deficiencies for attaining fundamental development goals, such as education, health, livelihood security, and empowerment and rights, whereas specific capacity refers to the tools and skills that enable people, systems, and institutions to prepare for and effectively respond to specific climatic threats. For example, traditional ecological knowledge can contribute to specific capacity by drawing on what have been experienced as dangerous environmental conditions in the past, what has been learned about safe travel across snow, ice, and rivers, and by adjusting subsistence activities according to the changing environmental conditions (Ford et al. 2006). Traditional means for transport and timing of subsistence use, harvest equipment and methods, and processing and storing food may not always be sufficient for responding to the challenges faced (Cold et al. 2020). In such cases, the use of alternative subsistence resources, flexibility in timing of harvest, changes in mode of transportation and travel routes to access resources, and acquisition of new equipment for harvest or communication are examples of measures that can enhance the capacity of Indigenous subsistence users to prepare for and respond to climate threats.

Eakin et al. (2014) argue that specific capacities to respond to climate threats cannot be seen in isolation from the generic capacities for addressing the multiple stressors that cause structural deficiencies that undermine communities' ability to adapt to change. For example, low household income and high cost of equipment may undermine the specific capacities related to taking advantage of new tools and technologies for responding to environmental changes. The role of generic capacity to adapt

${ }^{1}$ Institute of Social and Economic Research, University of Alaska Anchorage, ${ }^{2}$ Arctic Sustainability Lab, UIT - the Arctic University of Norway, Tromsø, Norway, ${ }^{3}$ Department of Environment and Society, Utah State University, Logan 
to changing environmental conditions was demonstrated by Brinkman et al. (2014), who found fuel costs to be a major barrier for adaptation among rural residents of Alaska when gathering subsistence resources with a motorized vehicle. Rising fuel costs and limited finances over the last 10 years had resulted in a reduced number of trips and shorter distances traveled. Their study also showed specific capacities to respond to changes by sharing fuel costs with family and friends and by conducting more multipurpose subsistence trips. Overall, the mixed cashsubsistence economy that combines subsistence use with wage labor and monetary income is supported by social networks of sharing food, labor, and equipment, which enhances community resilience and thus contributes to the generic capacity to respond to climate stress and shocks (BurnSilver et al. 2016, Fall 2016). Similarly, education and engagement between traditional and western knowledge systems can enhance adaptive capacity through early warning systems and information about weather events and sea ice conditions (Alessa et al. 2016, Caron et al. 2020, Perera et al. 2020, Wiggins and Turner-Bogren 2020). Incorporating both knowledge systems can enhance the capacity of Indigenous communities to participate in policy and decision making and to respond to change (Cold et al. 2020).

\section{Technology and adaptation}

What is the role of technology in the adaptive capacity of subsistence users and their communities to respond to changing environmental conditions? That was the focus of this study. Technology is broadly defined as tools that can be used to change how people engage or relate to the landscape or society (Borgmann 1984, Aporta and Higgs 2005). The creation and adoption of technology is not new among Indigenous cultures. Throughout history Indigenous peoples have changed modes of transportation, hunting and fishing equipment, and communication technologies (Slobodin 1962, Dyson 1986, Schroeder et al. 1987). With the concerns of climate change today there is a need to further understand the ways in which technology affects adaptive capacity in the Arctic (IPCC 2019), both as an enhancer and detractor. Many tools can potentially build capacities to adapt to climate changes, including electronic devices (e.g., GPS, cell phones, computers, etc.), hand-made (e.g., fishing rods, hooks, etc.), manufactured (e.g., snowmachines, rifles, etc.), or digital media (e.g., Facebook, YouTube, etc.). Given the potential of technology to affect numerous dimensions of Indigenous societies, both positive and negative effects on the adaptive capacity for responding to change can be expected. For example, climate-smart technologies, such as the SmartICE information system about safe sea ice traveling, can enhance the specific capacity to respond to natural hazards (Bell et al. 2014). Other examples include replacing small boats with larger ones to respond to increased storminess and rougher water, or investing in boats with shallower bottoms to respond to lower water levels in rivers (Gearheard et al. 2011, Eicken et al. 2014, Brinkman et al. 2016, Cold et al. 2020). The role of communication technology for the capacity to respond to climate change is also two-sided. On the one hand, technology is considered beneficial for navigating climate-related challenges by providing the means of sharing information and communication tools (Aporta and Higgs 2005, Pearce et al. 2010, Castleton 2016, Johnson et al. 2016). On the other hand, the use of internet and social media is considered by some to reduce engagement in subsistence activities and limit the transfer of traditional knowledge from older to younger generations (Aporta and Higgs 2005, Holen et al. 2012). The high cost of equipment can also create a barrier for youth to participate in subsistence (Brown and Godduhn 2015).

Although technology can help prepare for and manage specific climate-related vulnerabilities (Aporta and Higgs 2005, Pearce et al. 2010, Johnson et al. 2016), there are few studies that have empirically investigated the role of technologies for enhancing specific capabilities to climate threats. Furthermore, Arctic Alaska suffers from many inherent inequalities that could potentially undermine the generic capacity to respond to changing environments and cope with extreme weather events. Income is often lower in rural Arctic communities than in urban areas (Goldsmith 2010, Hajizadeh et al. 2018), and wage labor or other sources of income is important for making use of novel technologies. Access to high-quality education is also an issue because retaining qualified teachers in rural Alaska and Nunavut is a challenge (Goldsmith 2010, Kaden et al. 2016, Rodon and Lévesque 2018). Furthermore, health in some regions is negatively affected by the lack of piped water and sewer services in rural Alaska, resulting in poor oral hygiene and higher rates of infectious diseases (Thomas et al. 2016, Mosites et al. 2020). Arctic communities commonly have poor water treatment systems that make them vulnerable to heavy rainfall and rapid snowmelt, which can contaminate surface water and increase the likelihood of waterborne diseases (Harper et al. 2020).

Our study was designed primarily to investigate the role of technology in building specific capabilities for subsistence users to respond to climate threats, but we also investigated the implications of generic capacity for climate change adaptation. Given the broad and multidimensional impacts of technology on adaptive capacity (AC), we argue that it is not enough to simply state how technology affects AC. There is the need to further examine how technology has promoted or negated different types of AC, vulnerabilities, and trade-offs (Gupta et al. 2010). For this reason, we empirically explored the relationship between technology and both specific and generic capacity in three remote communities in Arctic Alaska. These communities were all primarily Alaska Native ( $>85 \%$ ), have mixed subsistence-cash economies, and have faced amplified environmental and social changes (Magdanz et al. 2010, Braem 2012, Moerlein and Carothers 2012, Oceana and Kawerak 2014, AKDCCED 2019, AKLWD 2019). As is the case with many remote communities of rural Alaska, these three communities are at a structural disadvantage compared to urban areas because of low incomes and graduation rates, high unemployment, and health disparities (Goldsmith 2010, Schweitzer et al. 2015, Towne et al. 2014, Bear et al. 2020). The need to enhance generic capacity for addressing basic human needs in these communities makes them particularly suitable for understanding the interplay between specific and generic capacity, and the interplay of forms of capacities and technologies for adapting to environmental change. We asked: How do Indigenous subsistence users employ different technologies to enhance specific capacity in response to climate threats? Are these technologies useful for adapting to and coping with challenges posed by climate change? How do multiple stressors that cause structural deficiencies in communities influence peoples' awareness, motivation, and ability to adapt to challenges resulting from rapid environmental change? And 
finally, how does technology influence the generic capacity in the communities?

\section{METHODS}

\section{Study region}

The three communities participating were Noatak ( 580 residents; 2017), Noorvik (669; 2017), and Brevig Mission (425; 2017; AKLWD 2019), as shown in Figure 1. They were chosen because of our previous knowledge of their interests and our connections to these communities. Like many communities in rural Alaska, they all have mixed subsistence-cash economies with extensive sharing networks (Ahmasuk et al. 2008, Magdanz et al. 2010, Braem 2012). Noorvik and Noatak are both located inland within the Northwest Arctic Borough (NWAB), with residents who are primarily Iñupiat, whereas Brevig Mission is located further south along the coast in the Nome Census Area (NCA), with residents who are mixed Iñupiat and Yupik. Median household incomes are higher in Noatak $(\$ 51,250$ in 2015$)$ and Noorvik $(\$ 40,833)$ than Brevig Mission (\$32,344), largely thanks to the Red Dog Mine, which provides employment and benefits to local shareholders (Haley and Fisher 2012, ACS 2015). In 2000, 44\% and $12 \%$ of Noatak and Noorvik residents were employed at the mine, respectively (Loeffler 2015). Although jobs at the Red Dog Mine are limited, benefits from employment ripple throughout the community and provide increased wages in the region, compared with the Nome Census Area (Berman et al. 2020). Over half of residents in Brevig Mission live in poverty (58\%), which is far greater than Noatak (25\%) or Noorvik (37\%; ACS 2015). Unemployment rates are high in all three (Brevig Mission 34\%; Noatak $22 \%$; Noorvik $38 \%$ ), with a large portion of residents not participating in the labor force (Brevig Mission 40\%; Noatak 47\%; Noorvik 45\%; ACS 2015).

Fig. 1. Three Alaska communities where interviews about technology and society were conducted in March 2017.

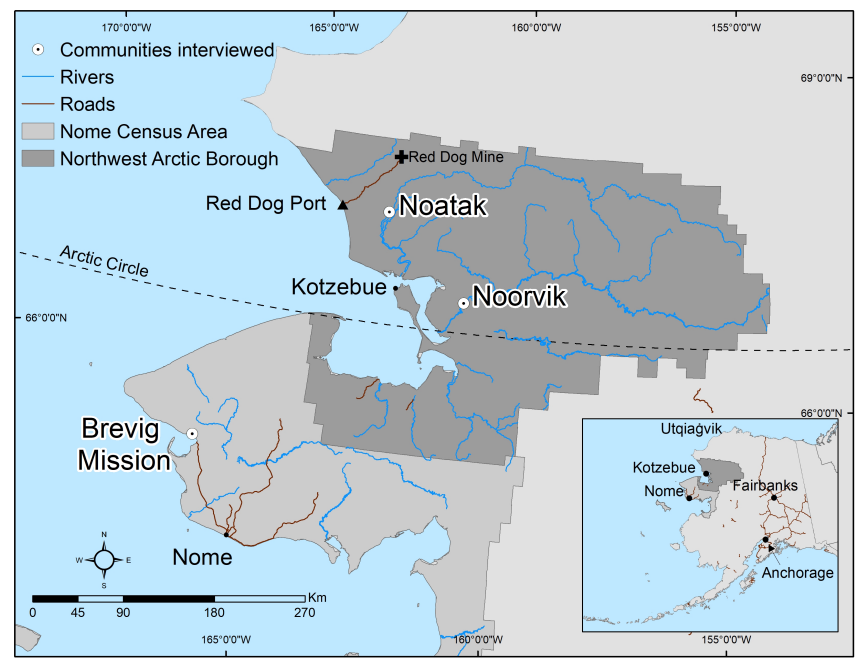

\section{Research design}

Preparations and design of interviews and Q-sort Prior to conducting interviews, we reviewed literature to identify how technology could address some of the social and environmental challenges in the Arctic, such as those relating to unpredictability, hazards of travel, changes in resource abundance, outmigration, and loss of traditional knowledge (see Table 1). We looked for both specific capabilities for responding to change in environmental conditions, as well as the use of technologies for enhancing capabilities for addressing some of the social and economic challenges that communities are facing. We used these results to design the interview guide and the Q-sort analysis procedures.

\section{Semi-structured interviews}

We were primarily interested in individuals who spend time out on the land interacting with the environment and harvesting resources. A local resident in each community was employed to help recruit subsistence harvesters who were active in the previous year. We used semi-structured interviews (Galleta and Cross 2013), with individuals in Noatak $(n=12)$, Noorvik $(n=11)$, and Brevig Mission $(n=12)$. We believe that our participants represent the diversity in uses of technology for subsistence and opinions on the topic because these communities are small $(<700)$ and relatively homogenous in terms of ethnicity and lifestyle. Interview questions were semi-structured with the goal of eliciting how technology contributes to adaptive capacity (Appendix 1). During interviews we discussed past (10 years) and current use of technology, how technology has influenced subsistence and the community, and how technology is being used to adapt to a changing climate. The semi-structured format of interviews served to uncover emerging issues not identified a priori and to provide empirical examples of how technology is being utilized by the interviewees. Responses were then associated with different types of AC.

\section{$Q$-sort analysis}

In addition to interviews, we also conducted a Q-sort analysis with a subset of participants (i.e., key respondents) who expressed interest and provided in-depth feedback and insights during the interview about the role of technology in their community (Noatak, $\mathrm{n}=6$; Noorvik, $\mathrm{n}=7$; Brevig Mission, $\mathrm{n}=8$ ). Q-sort is a semi-qualitative method used to identify different patterns of thought or topologies (McKeown and Thomas 2013, Zabala and Pascual 2016), and we used Q-sorting to capture the diversity of attitudes toward technology (Brown 1980, Watts and Stenner 2012, Zabala et al. 2018). Prior to conducting the Q-sort, we used our familiarity with the communities (Schmidt 2015, Schmidt et al. 2018), peer-reviewed literature (Magdanz et al. 2010, Braem 2012, Moerlein and Carothers 2012, Carothers et al. 2014), and questionnaires (Brinkman et al. 2014) to develop 25 Q-sort questions (Appendix 2). Factors captured by the statements included positive or negative views of technology, subsistence, environment (i.e., climate change and contaminants), and the economy (i.e., jobs and money). The R package qmethod was used to perform a factor analysis with a varimax rotation of the factor loadings (i.e., variance and eigenvalues; Zabala 2014). Factors were retained if they had an eigenvalue of one or above and substantive meaning, that is, the factor made sense (Watts and Stenner 2012, Zabala and Pascual 2016). We also calculated the median rank of each statement to assess overall agreement with the statements.

Interviewees were also asked to list the top three important issues for their community, and whether technology is having a positive 
Table 1. Changes facing remote communities in the Arctic, actual or potential adaptation actions, and ways that technology could be utilized.

\begin{tabular}{llll}
\hline \hline Type & Changes & Adaptation actions & Role of technology \\
\hline Environment/ & Increased unpredictability (Hinzman et al. & GPS collars on animals (Prichard et al. & Monitoring and data sharing (Prichard et \\
Climate & 2005, Huntington et al. 2005, Panikkar et & 2001) & al. 2001)
\end{tabular}

Sonar stations to count fish (Mueller et al. Monitoring and data sharing (ADFG 2006) 2020a, b) Development of more accurate online Access to information (Archer et al. 2017) weather tools (Caron et al. 2020, Wiggins and Turner-Bogren 2020)

Creation of social media networks (Castleton 2016, Archer et al. 2017, ANTHC 2018)

Hazardous travel conditions (Huntington Cameras (Gearheard et al. 2011) et al. 2005, Pearce et al. 2010, Huntington et al. 2017)

Videos and pamphlets (Schneider et al. 2013)

Investing in safety equipment (Pearce et al. 2010)

Access to information and social cohesion (Castleton 2016, Archer et al. 2017)

Monitoring and data sharing (Eicken et al. 2014, Gearheard et al. 2011)

Documenting new knowledge (Schneider et al. 2013)

More coverage, access to affordable equipment

Navigational tools (Ford et al. 2007,

Huntington et al. 2017)

Changes in abundance of subsistence

Development of online monitoring tools

Access to knowledge resources (Huntington et al. 2005, Johnson et al. 2016)

Creation of social media networks (Archer et al. 2017)

Use of digital media to document knowledge

Online repositories of knowledge, story maps (Arruda and Krutkowski 2017)

Video games with learning embedded

Lower interest among youth (RaymondYakoubian et al. 2014)

Loss of schools (Yardley 2009, Kraegel 2019) Games 2016)

Online classes (Beck et al. 2005, Hudson 2015)

Home schooling (Sullivan 2016)

Outmigration (Martin 2009, Heleniak and Creation of social media networks Bogoyavlensky 2015)

(Carson and Peterson 2016)

Economic

Increased need for wage incomes (Holen et al. 2012, Moerlein and Carothers 2012)

Access to knowledge and social cohesion

Knowledge transfer

Knowledge transfer

Knowledge transfer and having fun while learning (OneWorld Classrooms 2007)

Faster internet speeds for increased connectivity

Faster internet speeds for increased connectivity

Maintain connections with residents,

family who may have left

Faster internet speeds for increased connection to employers or negative influence on these issues. The responses were ranked using a point system with the top priority listed receiving three points, the second two points, and the third priority one point. The points were then totaled to determine which issue accumulated the most points. To reduce the number of categories, some identified issues were grouped into themes. Subsistence included concerns about sport hunting and access by hunters outside the community. Culture, heritage, and values included those specific issues plus sharing, helping each other, respect, honesty, and responsibility.

\section{RESULTS}

\section{Background}

We interviewed residents from Noatak, Noorvik, and Brevig Mission in March 2017. Most interviewees obtained at least a high school education or equivalent $(86 \%)$ and worked seasonally $(37 \%)$ or part-time $(23 \%)$, and all harvested subsistence resources. The most common resources harvested were caribou or moose
(97\%), fish (97\%), and waterfowl (86\%). All interviewees of Brevig Mission harvested marine mammals, whereas approximately half of interviews in Noatak $(50 \%)$ and Noorvik $(55 \%)$ harvested them.

\section{Technology and specific capacity}

Technology has influenced subsistence in the last decade. Interviewees noted it has become easier to locate animals $(70 \%)$ and hunt $(66 \%)$. Technology is reported to have increased communication with other harvesters $(71 \%)$, safety $(45 \%)$, and sharing of harvests $(89 \%)$. Balancing subsistence with employment was also improved with people being able to squeeze trips in between other obligations (63\%). Within the last five years, technology is perceived as helpful for adapting to environmental changes for all interviewees in Brevig Mission, all but one respondent in Noatak, and most in Noorvik (73\%). Technology can be used to adapt to various environmental changes, but there was variation is its use among our communities (Fig. 2). Extreme weather was the most common challenge our communities used 
technology to overcome $(89 \%)$ by obtaining information on weather from various sources including radio, weather apps, and calling hotlines or friends. GPS was mentioned as a tool to guide travelers during whiteout conditions. Fog was a common issue along the ocean coast in Brevig Mission, with people calling other communities, contacting pilots, or using their GPS units to guide them safely. One respondent stated that "GPS will bring you right to where you're at if it is foggy" (Brevig Mission 13).

Fig. 2. Environmental conditions for which interviewees reported using technology to help overcome natural hazards while carrying out subsistence activities or traveling.

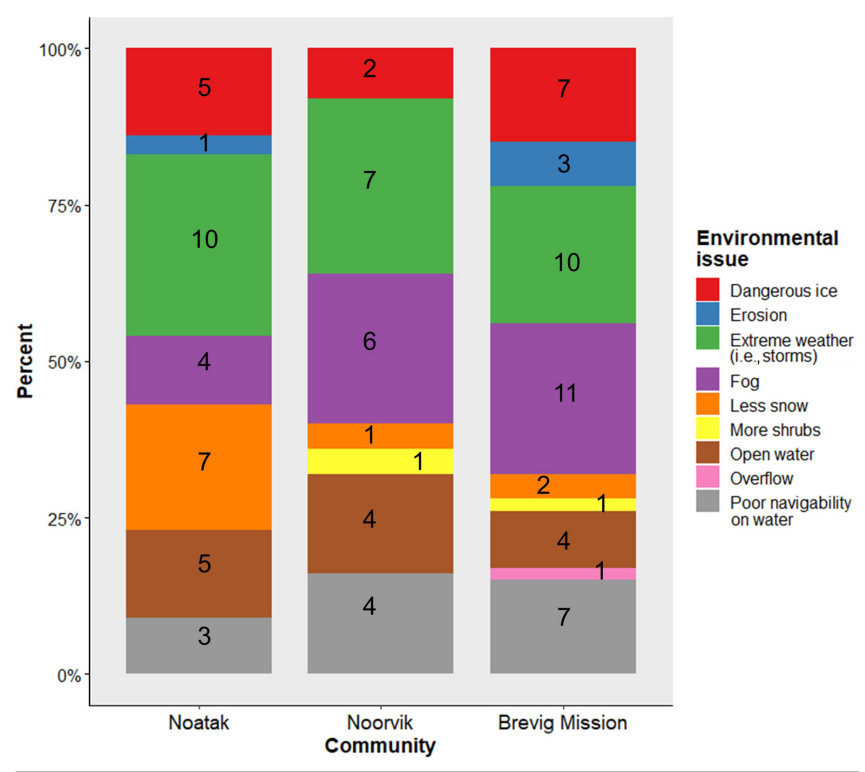

Interviewees in Noatak found technology helpful for dealing with low snow $(58 \%)$ because "snow conditions that used to occur in October in the 1980s now do not happen until December or January" (Noatak 1). Switching technologies is one way to deal with lack of snow. One harvester commented that it "seems like we're going to be riding 4-wheelers all year round soon" (Brevig Mission 12).

However, in some instances there is nothing residents can do but wait for snow (Noatak 13; Fig. 3A). When snow does not adequately accumulate, increases in shrubs can cause deep pockets of snow to occur causing snow machines to get stuck (Fig. 3B), and some interviewees have responded by purchasing machines with more power, a longer track, and wider skis to power out of deep pockets and increase buoyancy on top of snow. As with the lack of snow, the "waiting game" was also described as a response to a lack of sea ice, but in this case the internet was helpful for checking updates and knowing when to travel. To overcome higher air temperatures, some residents have turned to "fan-cooled engines, because snow is needed to keep the liquidcooled snow machines cool" (Noatak 2).

Although technology can be used as a tool to adapt to specific climate related challenges, interviewees also noted it can create vulnerabilities (26\%). Equipment failures were mentioned, such as "A broken belt left me stranded once" (Noatak 2), or "Glitches in the electrical lines, then you don't know how to work on it" (Brevig Mission 4).
Fig. 3. Environmental challenges faced by residents in rural Alaska: (A) no snow in Noatak in November 2019; (B) deep snow within shrubs outside of Noatak March 2017.

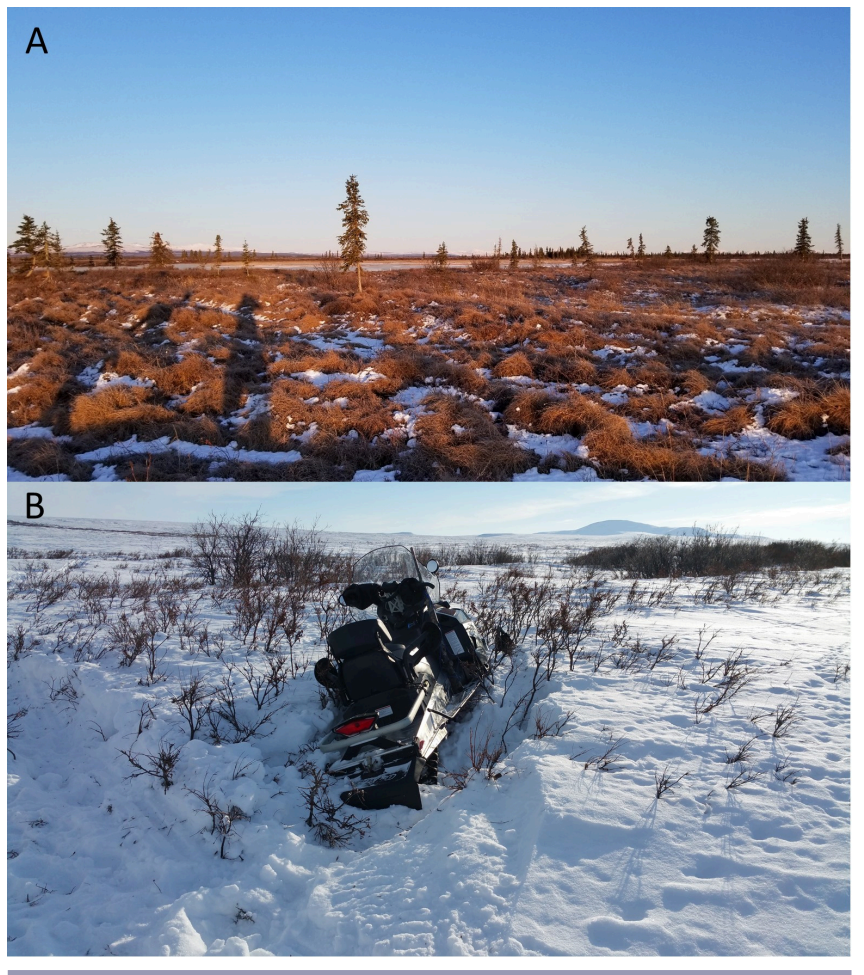

Safety was also a big concern for many people, leading to comments such as this: "I'd like to see way more GPSs, and these ones right there, the SPOTS [emergency locator beacons]. Every local hunter uses it because they need it out there. If they need help, they call on the help. They relay it over [very high frequency radio (VHF)], and search and rescue goes out" (Noorvik 12).

Interviewees did comment that technology can embolden some people to go out alone or in unsafe conditions: "It [vulnerability] depends who you are and the weather" (Noatak 12). One way that people try to reduce vulnerability is by drawing on and teaching local knowledge. For example, "Mostly around here [Noatak] we to try to teach the kids where they're at. We just show them the mountains where we're at. I show them all where we're at going upriver, downriver. That's how we teach. That's how I learned from the elders, teach us where we're at. I ask him every time, Where's this? Sugar. OK, you're doing good. It's like passing generation to generation on this side of the land, what you do to contribute. We should know where the south spots are, which river not to go" (Noatak 11).

However, not everyone was certain that traditional knowledge is being successfully passed along to younger people. Some feared that too much dependence on technology in conjunction with the loss of traditional knowledge could set people up for a dangerous outcome when traveling, hunting, fishing, or gathering. As the quote above illustrates, maintaining one's traditional knowledge is important in the event of technology failures. Part of the loss of traditional knowledge was reported as the result of competition among youth with television, video games, internet, 
Fig. 4. Results from Q-sort on attitudes toward technology by interviewees in Noatak, Noorvik, and Brevig Mission in March 2017. One interviewee did not sort into any group.

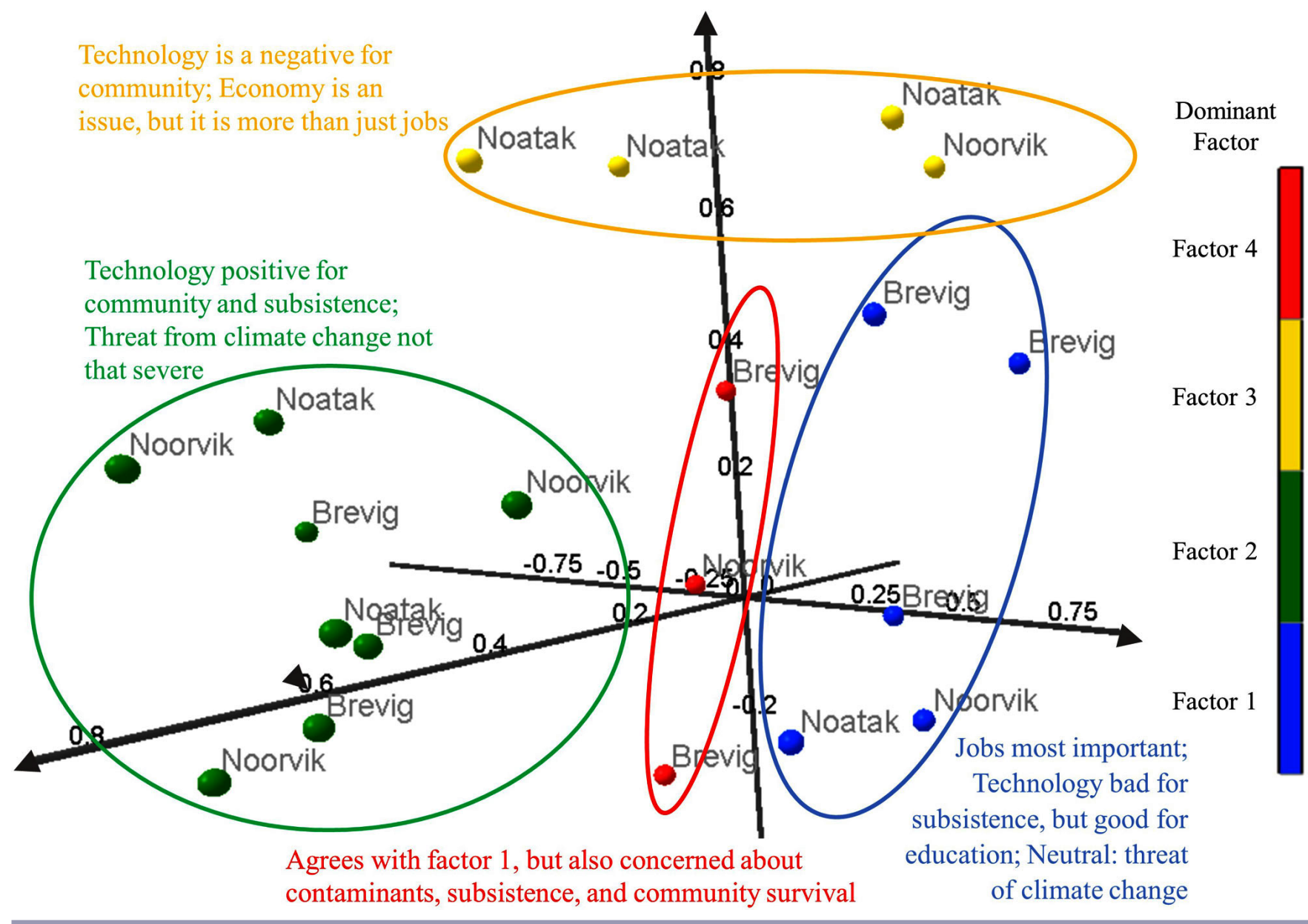

etc., which people said makes children less engaged in subsistence (71\%). Other downsides included financial burden of purchasing, maintaining, and operating equipment (34\%) and increased vulnerability $(23 \%)$. Vulnerability as identified by interviewees included getting lost, reductions in safety, and getting stuck or stranded.

\section{Technology and generic capacity}

Attitudes toward technology varied among community members, but a majority of interviewees in Noorvik $(64 \%)$ and Noatak $(58 \%)$ believed technology has a positive effect on their respective community, whereas less than half of interviewees in Brevig Mission felt technology had an overall positive effect (42\%). Qsorts allowed us to examine the role of technology more holistically through the inclusion of other community issues beyond climate change and subsistence and to assess attitudes regarding its use. Our Q-sort results indicate there are four factors that best capture interviewees' attitudes toward technology and the issues residents face (Fig. 4; Appendix 3). Q-sort results indicate that $56 \%$ of the variation in the responses is explained by the four identified factors, which is on the weaker end. Variance reflects the amount of variability within the study. The first two factors contributing equally (eigenvalue $=3.6$, variation explained
$=17 \%$ ) and slightly less among the third (eigenvalue $=2.5$, variation explained $=12 \%$ ) and fourth (eigenvalue $=2.2$, variation explained $=10 \%$ ). The variance for each factor indicates the common variability shared by a set of q-sorts (Watts and Stenner 2012)

Each of the four factors were a mix of different interviewees highlighting the diversity of perspectives within rural Alaska communities on these topics. The first group included five key respondents $(24 \%)$, who prioritized the importance of jobs for their community and felt that technology was not beneficial for subsistence, but helpful for education. The second group $(38 \%)$ believed that technology was beneficial for the community and for subsistence, whereas the third group (19\%) disagreed and felt technology was not beneficial for the community in any way. Like the first group, the third group agreed the economy was an important issue, but not jobs specifically. The fourth group (14\%) concurred with the second group that technology was helpful for subsistence, but more important issues were contaminants and the importance of subsistence for community survival. One key respondent did not identify with any group. Overall, key respondents believed technology was positive and an important tool for facing future challenges (Appendix 2). Most key 
Table 2. Important issues identified by interviewees among the communities. A tiered point system was used with first, second, and third mentions getting three, two, and one points, respectively. Issues counted under "other" include leadership, suicide prevention, technology, communication, and gambling.

\begin{tabular}{|c|c|c|c|c|c|c|c|c|}
\hline \multirow[b]{2}{*}{ Issue } & \multicolumn{2}{|c|}{ All } & \multicolumn{2}{|c|}{ Noatak } & \multicolumn{2}{|c|}{ Noorvik } & \multicolumn{2}{|c|}{ Brevig Mission } \\
\hline & $\%$ & Points & $\%$ & Points & $\%$ & Points & $\%$ & Points \\
\hline Jobs/economy & 16 & 28 & 10 & 6 & 26 & 13 & 13 & 9 \\
\hline Culture, heritage, and values & 14 & 25 & 16 & 10 & 4 & 2 & 19 & 13 \\
\hline Subsistence & 14 & 25 & 25 & 15 & 10 & 5 & 7 & 5 \\
\hline Education & 10 & 18 & 11 & 7 & 4 & 2 & 13 & 9 \\
\hline Fuel price/quality & 8 & 15 & 16 & 10 & 8 & 4 & 1 & 1 \\
\hline Safety & 8 & 15 & 10 & 6 & 18 & 9 & 0 & 0 \\
\hline Drugs/alcohol/cigarettes & 7 & 13 & 5 & 3 & 10 & 5 & 7 & 5 \\
\hline Housing & 4 & 7 & 0 & 0 & 0 & 0 & 10 & 7 \\
\hline Health and health care & 3 & 6 & 0 & 0 & 8 & 4 & 3 & 2 \\
\hline Elders & 3 & 5 & 0 & 0 & $0 \%$ & 0 & 7 & 5 \\
\hline Food costs & 3 & 5 & 0 & 0 & 6 & 3 & 3 & 2 \\
\hline Youth & 3 & 5 & 0 & 0 & 0 & 0 & 7 & 5 \\
\hline Other & 7 & 12 & 7 & 4 & 6 & 3 & 7 & 5 \\
\hline
\end{tabular}

respondents believed that technology was not effective at increasing capacity to participate in natural resource management (Appendix 2). Two reasons were given for this perspective: management was viewed largely as something that happens at a remove from residents, or the technology currently used to learn about management (e.g., radio, phone, and word of mouth) has existed for quite some time. Table 2 shows issues identified as top concerns among our communities. Jobs and the economy were number one ( 28 out of 179 total points), followed by issues related to culture, heritage, and values (25 of 179). Culture, heritage, and values included issues related to honesty, sharing, respect, and responsibility. Although subsistence is intertwined with culture, it was mentioned several times and tied for second.

Even though a majority of interviewees were concerned about climate change $\left(89^{\circ} \%\right)$, it was not directly identified as a top concern (Appendix 2). However, changes in climate can have ripple effects into other issues like subsistence and contaminants (IPCC 2014, 2019). Overall, the variation in concerns among our communities was high. Noatak, which is close to the Red Dog mine, ranked employment and jobs lower than the other two communities. Brevig Mission residents, who hunt marine mammals in the ocean, listed fuel prices as a top concern (Table 2). Fuel is available from Red Dog for residents of Noatak. Another priority for participants was culture, heritage, and values (Table 2). Interviewees of Noatak (58\%) and Brevig Mission $(67 \%)$ believed that technology can be used to pass down traditional knowledge that is rich in culture, but the participants from Noorvik were more skeptical that technology is helpful $(36 \%)$. Most interviewees agreed that technology facilitated taking children out while doing subsistence activities (83\%), which exposes children to activities and could facilitate the passing along of traditions. However, some reported that technology can also undermine traditional knowledge because people rely less on what elders have taught them and depended too much on technology (31\%): "GPS might be better than what they had in the past, but it is still important to know when it's gonna get fog ... and not everyone has a GPS. Knowledge of the stars, moon, and mountains is important" (Noatak 4).
Overall, there were eight technologies mentioned that would be helpful for the future, and most of them supported increased communication or coverage, such as cellular network (32\%) and a repeater to allow cellular signals to travel further (21\%). Safety was also a high priority with interviewees desiring more GPS units $(18 \%)$, personal locator beacons $(7 \%)$, satellite phones $(7 \%)$, and VHFs $(7 \%)$.

\section{DISCUSSION}

Indigenous subsistence users employ a wide variety of technologies to enhance their specific capacity to respond to environmental conditions and climate threats. Most important is the use of technology to navigate in foggy conditions and to cope with extreme weather events. The latter was viewed as crucial, especially given that extreme weather events are expected to increase in frequency, magnitude, and severity in the coming decades (Walsh et al. 2020). The majority of those interviewed emphasized the increased capacity of accessing and locating animals, better communication with other subsistence users about environmental conditions, enhanced safety when traveling, and better tools for sharing harvests. Some also mentioned the need to switch to new snow machines to tackle the reduced amount of snow in early winter.

Despite recognizing climate threats to a subsistence way of life, as well as the role of technology for enhancing the specific capacity of addressing these threats, residents did not consider climate change the top priority for the communities. These responses are consistent with other studies that found issues of local jobs and well-being as more important (Bali and Kofinas 2014, Forbes and Kofinas 2014). Furthermore, whereas residents found technology is positive for enhancing capacity to adapt to change, many participants also emphasized the downsides of technologies, including the reduction in knowledge transfer due to the loss of youth interest in subsistence. These responses are similar to a study of communities in Nunavut where residents reported concerns that youth are more interested in jobs, money, and technology than subsistence, thereby threating transmission of traditional knowledge (Panikkar and Lemmond 2020). The generic capacity to address economic development in the three 
communities were considered more important than the need to increase income, employment, improve education, and strengthen cultural identity.

Even though there are many benefits to technology, it was not viewed as a "saving grace." One of the reasons for skepticism regarding the benefits of technology is that investing in new and helpful equipment is costly, and relying on these tools can increase vulnerability if owners are not able to cover the cost of maintenance. Equipment failure, which can result from lack of maintenance or exposure of electronics to harsh environmental conditions, was mentioned as a concern. As noted by many interviewees, technology alone cannot keep one safe; the users' knowledge and state of awareness are critically important. Disengagement, physically and socially, through the use of technology was a concern among Inuit harvesters in Nunavut as it was in our study (Aporta and Higgs 2005). This disconnection could increase vulnerability of Arctic subsistence users. In the Nunavut study, mechanical breakdown, running out of fuel, and getting equipment stuck were often cited as a reason for requiring search and rescue operations (Clark et al. 2016). Lack of traditional knowledge (Panikkar and Lemmond 2020) coupled with a false impression of safety from technologies and new communication tools may increase vulnerability. Thus, although technology has the potential to build community and individuals' capacity to respond to climate threats, there are issues that need to be resolved to avoid exacerbating related vulnerabilities.

The concern about cultural continuity, intergenerational transfer of knowledge and skills and youth participation in subsistence activities is not unique to the three communities in our study. Time spent outdoors has been declining over the past decades (Louv 2008), including among Indigenous youth of the Canadian Arctic (Pearce et al. 2011, Holen et al. 2012, Tremblay 2018, Panikkar and Lemmond 2020). Participants in our study noted the diminishing capacity to respond to climate threats and environmental adversities by use of traditional ecological knowledge. Using new modes of transport and communication tools to enhance the specific capacity to respond to climate threats can make youth less aware of traditional ways of reading the landscape and thus less capable of adapting to change and coping with adverse weather. Wage labor and compulsory schooling are usually proposed as the cause for reduced participation in subsistence hunting and fishing, but concerns were also related to the time youth spent on social media, games, and the internet, which affects their general interest and motivation to engage in subsistence activities. Despite these concerns, the majority of interviewees believed that technology could also be used to help pass knowledge along to younger generations and strengthen the cultural identity relating to subsistence activities. Although community-based monitoring programs, which use technology, are not specifically designed to preserve traditional knowledge, they do promote the documentation and preservation of local ecological knowledge for future generations (Gearheard et al. 2011, ANTHC 2018). This perspective was also evident in a study from Iqaluit in the Canadian Arctic, suggesting that social media in particular could revitalize traditions and language, facilitate intergenerational transmission and sharing of knowledge, and strengthen cultural identities relating to subsistence activities (Csonka and Schweitzer 2004, O'Keefe et al. 2009).
Eakin et al. (2014) contend that both specific and generic adaptive capacity play a role in attaining sustainable adaptation in the long term. Our participants expressed more concern about the generic capacity to promote basic community development needs, improve education, and maintain cultural traditions and subsistence, rather than to increase the capacity to address climate threats. Technology has been beneficial for Arctic residents in terms of their specific capacity to respond to climate threats, as evidenced by our work and the larger amount of literature (Table 1), but the role of technology in enhancing generic capacity to participate in governance, preserve language, obtain employment, improve income, access education, and participate in decision making is less clear. For example, some school districts in 2017, when interviews were done, did not recommend teachers use online tools in kindergarten to grade 12 because of low bandwidth (Nicosia 2019). A 2021 workshop illustrates that internet access is still an issue for education and training in Alaska (Voice and ICAS 2021). Very few interviewees thought that technology was helpful for participating in governance, such as wildlife or fish regulatory meetings, and our research shows that technology has been limited in its ability to improve generic capacity. While visiting the communities, we observed land-based phones being used to participate in a regulatory meeting and by school children attending classes in other communities rather than taking advantage of internet access. Finding new ways to utilize technology to make improvements in institutional capacity are needed. Many communities in rural Alaska experienced that the youth leave to pursue college or technical degrees and do not move back; there are several reasons for this, one of which is lack of jobs (Huskey et al. 2004). Technology has the potential to improve education, but internet access, bandwidth, and costs are limiting the ability of rural residents to participate in virtual activities that could include classes and training (Falsey 2017, Voice and ICAS 2021). Teleworking from their homes is also a growing trend (Felstead and Henseke 2017), and could help attract youth who have pursued degrees, want jobs applicable to their education, but also desire a balanced traditional and modern lifestyle (GramHanssen 2018). Based on our literature review (Table 1), there are many opportunities to enhance the generic capacity to address some of these main challenges that the communities are facing and that go beyond the specific capacity to respond to climate threats.

\section{CONCLUSIONS}

Technology is important for enhancing the specific capacity to adapt to changing environmental conditions, natural hazards, and extreme weather events. It can also enhance generic capacity by facilitating the sharing of information and communication about environmental conditions. Increases in both types of capacity improve the ability of Arctic residents to reduce their vulnerability while out on the land and sea. On the other hand, our results show that technology can provide a false sense of security and embolden people to venture outside without a partner when conditions are unsafe. It was also suggested that relying on technology can potentially reduce one's awareness of the environment, and detract from the knowledge and skills necessary for adapting to shifting environmental conditions. Concerns about the lack of youth participation in subsistence were evident, but many interviewees expressed optimism that technology could preserve and facilitate the transmission of traditional knowledge to youth. 
Technology has the potential to help maintain subsistence traditions, cultural identity, and continuity, but this requires investments that involves institutions at multiple levels that can contribute to building generic capacity to meet development needs of communities in the Arctic.

\section{BROADER IMPLICATIONS}

Technology can be used to improve the specific capacity to adapt to challenges posed by climate change in the Arctic. One of the most important ways is to improve safety in a rapidly changing environment by improving monitoring, communication, and knowledge transmission by use of technology. If used wisely, the negative aspects of using technology can be offset by combining traditional knowledge with technology to enhance transmissions of traditions and culture between generations. To succeed with climate change adaptation, it is crucial that specific capacities are complemented by efforts to enhance the generic capacity to meet basic development needs of the communities. Enhanced generic capacity could also help address downsides such as reduced engagement among youth in subsistence and to address the financial costs of adopting technologies. Overall, technology could help people adapt to the complex challenges facing Arctic communities, including the transformations that are desirable from a local perspective.

\section{Responses to this article can be read online at:} https://www.ecologyandsociety.org/issues/responses. php/12605

\section{Acknowledgments:}

The authors gratefully acknowledge the residents of Noatak, Noorvik, and Brevig Mission. Research funding was provided by the National Science Foundation, award 1216399, the Belmont Forum project CONNECT-Global connections and changing resource use systems in the Arctic (Norwegian Research Council number 247474, U.S. National Science Foundation award 1534006), and the University of Alaska Anchorage Institute of Social and Economic Research.

\section{Data Availability:}

The datalcode that support the findings of this study are available on request from the corresponding author, JS. The datalcode are not publicly available because of University of Alaska Anchorage Institutional Review Board restrictions.

\section{LITERATURE CITED}

Ahmasuk, A., E. Trigg, J. Magdanz, and B. Robbins. 2008. Bering Strait Region local and traditional knowledge pilot project: comprehensive subsistence use study of the Bering Strait Region. Kawerak, Nome, Alaska, USA.

Alaska Department of Commerce, Community, and Economic Development (AKDCCED). 2019. Alaska community database online. Alaska Department of Commerce, and Economic
Development, Anchorage, Alaska, USA. [online] URL: https:// dcra-cdo-dcced.opendata.arcgis.com/

Alaska Department of Fish and Game (ADFG). 2020a. Commercial salmon fisheries: Yukon management area. ADFG, Division of Commercial Fisheries, Juneau, Alaska, USA. [online] URL: https://www.adfg.alaska.gov/index.cfm?adfg= commercialbyareayukon.salmon\#fishcounts

Alaska Department of Fish and Game (ADFG). 2020b. Fish count data search. ADFG, Division of Sport Fish, Juneau, Alaska, USA. [online] URL: https://www.adfg.alaska.gov/sf/ FishCounts/

Alaska Department of Labor and Workforce Development (AKLWD). 2019. Alaska local and regional information. AKLWD, Research and Analysis, Juneau, Alaska, USA. [online] URL: http://live.laborstats.alaska.gov/alari/

Alaska Native Tribal Health Consortium (ANTHC). 2018. Local environmental observer (LEO) network. ANTHC, Anchorage, Alaska, USA. [online] URL: https://www.leonetwork.org/en/ docs/about/about

Alessa, L., A. Kliskey, J. Gamble, M. Fidel, G. Beaujean, and J. Gosz. 2016. The role of Indigenous science and local knowledge in integrated observing systems: moving toward adaptive capacity indices and early warning systems. Sustainability Science 11:91-102. https://doi.org/10.1007/s11625-015-0295-7

American Community Survey (ACS). 2015. Selected economic characteristics. United States Census Bureau, Washington, D.C., USA. [online] URL: https://data.census.gov/cedsci/table? $\mathrm{g}=0400000 \mathrm{US} 02 \& \mathrm{~d}=\mathrm{ACS} \% 205-$ Year $\% 20$ Estimates $\% 20$ Data $\%$ 20Profiles\&tid=ACSDP5Y2015.DP03

Aporta, C., and E. Higgs. 2005. Satellite culture: global positioning systems, Inuit wayfinding, and the need for a new account of technology. Current Anthropology 46(5):729-753. https://doi.org/10.1086/432651

Archer, L., J. D. Ford, T. Pearce, S. Kowal, W. A. Gough, and M. Allurut. 2017. Longitudinal assessment of climate vulnerability: a case study from the Canadian Arctic. Sustainability Science 12:15-29. https://doi.org/10.1007/s11625-016-0401-5

Arctic Monitoring and Assessment Programme (AMAP). 2021. Climate Issues of Concern. AMAP, Arctic Council, Oslo, Norway. [online] URL: https://climate.amap.no/

Arruda, G. M., and S. Krutkowski. 2017. Arctic governance, Indigenous knowledge, science and technology in times of climate change self-realization, recognition, representativeness. Journal of Enterprising Communities: People and Places in the Global Economy 11:514-528. https://doi.org/10.1108/JEC-08-2015-0041

Bali, A., and G. P. Kofinas. 2014. Voices of the Caribou People: a participatory videography method to document and share local knowledge from the North American human-Rangifer systems. Ecology and Society 19(2):16. http://dx.doi.org/10.5751/ ES-06327-190216

Bear, U. R., N. L. Asdigian, J. Beals, S. M. Manson, and C. E. Kaufman. 2020. Health outcomes in a national sample of American Indian and Alaska Native adults: differences between 
multiple-race and single-race subgroups. PLoS ONE 15(12): e0242934. https://doi.org/10.1371/journal.pone.0242934

Beck, R. A., W. Weisner, K. Hinkel, H. Pesanti, B. Ellis, E. Beiswenger, W. Parker, M. Treadwell, S. Smith, L. Krogh, K. G. Hansen, and V. Peskov. 2005. Nutarniq: uniting the Arctic community with a wireless Arctic network for circumpolar communications. Polar Geography 29:43-78. https://doi. org/10.1080/789610165

Bell, T., R. Briggs, R. Bachmayer, and S. Li. 2014. Augmenting Inuit knowledge for safe sea-ice travel: the SmartICE information system. Pages 1-9 in Proceedings of 2014 Oceans. Institute of Electrical and Electronics Engineers, St. John's, Newfoundland, Canada. https://doi.org/10.1109/OCEANS.2014.7003290

Berman, M., R. Loeffler, and J. I. Schmidt. 2020. Long-term benefits to Indigenous communities of extractive industry partnerships: evaluating the Red Dog Mine. Resources Policy 66:101609. https://doi.org/10.1016/j.resourpol.2020.101609

Borgmann, A. 1984. Technology and the character of contemporary life: a philosophical inquiry. University of Chigago Press, Chicago, Illinois, USA.

Box, J. E., W. T. Colgan, T. R. Christensen, N. M. Schmidt, M. Lund, F. J. W. Parmentier, R. Brown, U. S. Bhatt, E. S. Euskirchen, V. E. Romanovsky, J. E. Walsh, J. E. Overland, M. Wang, R. W. Corell, W. N. Meier, B. Wouters, S. Mernild, J. Mård, J. Pawlak, and M. S. Olsen. 2019. Key indicators of Arctic climate change: 1971-2017. Environmental Research Letters 14(4):45010. https:// doi.org/10.1088/1748-9326/aafc1b

Braem, N. M. 2012. Subsistence wildlife harvests in Noorvik, Shungnak, and White Mountain, Alaska, 2008-2009. Special publication: SP2011-003. Alaska Department of Fish and Game, Division of Subsistence, Fairbanks, Alaska, USA. [online] URL: https://ibrary.alaska.gov/asp/edocs/2012/07/ocn798726160.pdf

Brinkman, T. J., W. D. Hansen, F. S. Chapin, G. Kofinas, S. BurnSilver, and T. S. Rupp. 2016. Arctic communities perceive climate impacts on access as a critical challenge to availability of subsistence resources. Climatic Change 139:413-427. https://doi. org/10.1007/s10584-016-1819-6

Brinkman, T., K. B. Maracle, J. Kelly, M. Vandyke, A. Firmin, and A. Springsteen. 2014. Impact of fuel costs on high-latitude subsistence activities. Ecology and Society 19(4):18. https://doi. org/10.5751/ES-06861-190418

Brown, C. L., and A. Godduhn. 2015. Socioeconomic effects of declining salmon runs on the Yukon River. Technical paper 398. Alaska Department of Fish and Game, Division of Subsistence, Fairbanks, Alaska, USA. [online] URL: http://www.adfg.alaska. gov/techpap/TP398.pdf

Brown, S. R. 1980. Political subjectivity: applications of Q methodology in political science. Yale University Press, New Haven, Connecticut, USA.

BurnSilver, S., J. Magdanz, R. Stotts, M. Berman, and G. Kofinas. 2016. Are mixed economies persistent or transitional? Evidence using social networks from Arctic Alaska. American Anthropologist 118(1):121-129. https://doi.org/10.1111/aman.12447
Caron, L. P., F. Massonnet, P. J. Klotzbach, R. J. Philp, and J. Stroeve. 2020. Making seasonal outlooks of Arctic sea ice and Atlantic hurricanes valuable - not just skillful. Bulletin of the American Meteorological Society 101:E36-E42. https://doi. org/10.1175/BAMS-D-18-0314.1

Carothers, C., C. Brown, K. J. Moerlein, J. A. López, D. B. Andersen, and B. Retherford. 2014. Measuring perceptions of climate change in northern Alaska: pairing ethnography with cultural consensus analysis. Ecology and Society 19(4):27. https:// doi.org/10.5751/ES-06913-190427

Carson, M., and G. Peterson, editors. 2016. Arctic resilience report. Arctic Council, Stockholm Environment Institute and Stockholm Resilience Centre, Stockholm, Sweden. [online] URL: https://www.sei.org/publications/arctic-resilience-report/

Castleton, A. 2016. Identity, community, and technology: reflections on the Facebook group Inuit hunting stories of the day. Études Inuit Studies 40:207-224. https://doi.org/10.7202/1055439ar

Chatwood, S., F. Paulette, G. R. Baker, A. M. A. Eriksen, K. L. Hansen, H. Eriksen, V. Hiratsuka, J. Lavoie, W. D. Lou, I. Mauro, J. Orbinski, N. Pambrun, H. Retallack, and A. Brown. 2017. Indigenous values and health systems stewardship in circumpolar countries. International Journal of Environmental Research and Public Health 14:20. https://doi.org/10.3390/ijerph14121462

Clark, D. G., J. D. Ford, T. Pearce, and L. Berrang-Ford. 2016. Vulnerability to unintentional injuries associated with land-use activities and search and rescue in Nunavut, Canada. Social Science \& Medicine 169:18-26. https://doi.org/10.1016/j. socscimed.2016.09.026

Cochran, P., O. H. Huntington, C. Pungowiyi, S. Tom, F. S. Chapin, III, H. P. Huntington, N. G. Maynard, and S. F. Trainor. 2013. Indigenous frameworks for observing and responding to climate change in Alaska. Climatic Change 120:557-567. https:// doi.org/10.1007/s10584-013-0735-2

Cold, H. S., T. J. Brinkman, C. L. Brown, T. N. Hollingsworth, D. R. N. Brown, and K. M. Heeringa. 2020. Assessing vulnerability of subsistence travel to effects of environmental change in Interior Alaska. Ecology and Society 25(1):20. https:// doi.org/10.5751/ES-11426-250120

Csonka, Y., and P. Schweitzer. 2004. Societies and culture: change and persistence. Pages 45-68 in Arctic human development report. Stefansson Arctic Institute, Akureyri, Iceland. [online] URL: http://www.svs.is/static/files/images/pdf files/ahdr/English version/ AHDR chp 3.pdf

Dankel, D. J., R. G. Tiller, E. Koelma, V. W. Y. Lam, and Y. J. Liu. 2020. The melting snowball effect: a heuristic for sustainable Arctic governance under climate change. Frontiers in Marine Science 7:17. https://doi.org/10.3389/fmars.2020.00537

Dyson, G. B. 1986. Baidarka. Alaska Northwest, Edmonds, Washington, USA

Eakin, H. C., M. C. Lemos, and D. R. Nelson. 2014. Differentiating capacities as a means to sustainable climate change adaptation. Global Environmental Change 27:1-8. https://doi.org/10.1016/j.gloenvcha.2014.04.013 
Eicken, H., M. Kaufman, I. Krupnik, P. Pulsifer, L. Apangalook, P. Apangalook, W. Weyapuk, and J. Leavitt. 2014. A framework and database for community sea ice observations in a changing Arctic: an Alaskan prototype for multiple users. Polar Geography 37(1):5-27. https://doi.org/10.1080/1088937X.2013.873090

Fall, J. A. 2016. Subsistence in Alaska: a year 2014 update. Alaska Department of Fish and Game, Division of Subsistence, Anchorage, Alaska, USA. [online] URL: https://www.adfg. alaska.gov/static/home/subsistence/pdfs/subsistence_update_2014. pdf

Falsey, J. L. 2017. For rural Alaska broadband, the 'middle mile' is everything. Alaska Daily News, 18 March. [online] URL: https://www.adn.com/features/business-economy/2017/03/18/forrural-alaska-broadband-the-middle-mile-is-everything/

Felstead, A., and G. Henseke. 2017. Assessing the growth of remote working and its consequences for effort, well-being and work-life balance. New Technology Work and Employment 32:195-212. https://doi.org/10.1111/ntwe.12097

Forbes, B. C., and G. Kofinas. 2014. Resource governance. Pages 253-289 in G. Fondal and J. Nymand Larsen, editors. Arctic Human Development Report. Nordic Council of Ministers, Copenhagen, Denmark. [online] URL: http://norden.divaportal.org/smash/get/diva2:788965/FULLTEXT03.pdf

Ford, J. D., G. McDowell, and T. Pearce. 2015. The adaptation challenge in the Arctic. Nature Climate Change 5:1046-1053. https://doi.org/10.1038/nclimate2723

Ford, J., T. Pearce, B. Smit, J. Wandel, M. Allurut, K. Shappa, H. Ittusujurat, and K. Qrunnut. 2007. Reducing vulnerability to climate change in the Arctic: the case of Nunavut, Canada. Arctic 60:150-166. https://doi.org/10.14430/arctic240

Ford, J. D., B. Smit, and J. Wandel. 2006. Vulnerability to climate change in the Arctic: a case study from Arctic Bay, Canada. Global Environmental Change 16:145-160. http://dx.doi. org/10.1016/j.gloenvcha.2005.11.007

Galletta, A., and W. E. Cross. 2013. Mastering the semi-structured interview and beyond from research design to analysis and publication. NYU Press, New York, New York, USA.

Gearheard, S., C. Aporta, G. Aipellee, and K. O'Keefe. 2011. The Igliniit project: Inuit hunters document life on the trail to map and monitor Arctic change. Canadian Geographer/Géographe Canadien 55:42-55. https://doi.org/10.1111/j.1541-0064.2010.00344. $\underline{\mathrm{X}}$

Goldsmith, S. 2010. Structural analysis of the Alaska Economy: what are the drivers? Institute of Social and Economic Research, University of Alaska Anchorage, Alaska, USA. [online] URL: http://hdl.handle.net/11122/4287

Gram-Hanssen, I. 2018. Leaving, staying or belonging: exploring the relationship between formal education, youth mobility and community resilience in rural Alaska. Polar Geography 41:1-25. https://doi.org/10.1080/1088937X.2017.1414083

Gray, S. T., C. T. Markon, M. Berman, L. Eerkes-Medrano, T. Hennessy, H. P. Huntington, J. Littell, M. McCammon, R. Thoman, and S. Trainor. 2018. Alaska. Pages 1185-1241 in D. R. Reidmiller, C. W. Avery, D. R. Easterling, K. E. Kunkel, K. L. M.
Lewis, T. K. Maycock, and B. C. Stewart, editors. Impacts, risks, and adaptation in the United States: fourth national climate assessment, Vol. II. U.S. Global Change Research Program. U.S. Government Publishing Office, Washington, D.C., USA. https:// doi.org/10.7930/NCA4.2018.CH26

Greaves, W. 2016. Arctic (in)security and Indigenous peoples: comparing Inuit in Canada and Sami in Norway. Security Dialogue 47:461-480. https://doi.org/10.1177/0967010616665957

Griffin, P. J. 2020. Pacing climate precarity: food, care and sovereignty in Iñupiaq Alaska. Medical Anthropology 39:333-347. https://doi.org/10.1080/01459740.2019.1643854

Gupta, J., C. Termeer, J. Klostermann, S. Meijerink, M. Van Den Brink, P. Jong, S. Nooteboom, and E. Bergsma. 2010. The adaptive capacity wheel: a method to assess the inherent characteristics of institutions to enable the adaptive capacity of society. Environmental Science \& Policy 13(6):459-471. https:// doi.org/10.1016/j.envsci.2010.05.006

Hajizadeh, M., M. Hu, A. Bombay, and Y. Asada. 2018. Socioeconomic inequalities in health among Indigenous peoples living off-reserve in Canada: trends and determinants. Health Policy 122:854-865. https://doi.org/10.1016/j.healthpol.2018.06.011

Haley, S., and D. Fisher. 2012. Shareholder employment at Red Dog Mine. Working paper 2012-2. University of Alaska Anchorage, Institute of Social and Economic Research (ISER), Anchorage, Alaska, USA. [online] URL: https://scholarworks. alaska.edu/handle/11122/3927

Harper, S. L., C. Wright, S. Masina, and S. Coggins. 2020. Climate change, water, and human health research in the Arctic. Water Security 10:100062. https://doi.org/10.1016/j.wasec.2020.100062

Heleniak, T., and D. Bogoyavlensky. 2015. Arctic populations and migration. Pages 53-103 in J. N. Larsen, and G. Fondahl, editors. Arctic human development report: regional processes and global linkages. Nordic Council of Ministers, Nordic Council of Ministers Secretariat, Nordisk Ministerråd, Copenhagen, Denmark. [online] URL: http://norden.diva-portal.org/smash/ record.jsf?pid=diva $2 \% 3$ A $788965 \&$ dswid $=-6693$

Hinzman, L. D., N. D. Bettez, W. R. Bolton, F. S. Chapin, M. B. Dyurgerov, C. L. Fastie, B. Griffith, R. D. Hollister, A. Hope, H. P. Huntington, A. M. Jensen, G. J. Jia, T. Jorgenson, D. L. Kane, D. R. Klein, G. Kofinas, A. H. Lynch, A. H. Lloyd, A. D. McGuire, F. E. Nelson, W. C. Oechel, T. E. Osterkamp, C. H. Racine, V. E. Romanovsky, R. S. Stone, D. A. Stow, M. Sturm, C. E. Tweedie, G. L. Vourlitis, M. Walker, D. A. Walker, P. J. Webber, J. M. Welker, K. Winker, and K. Yoshikawa. 2005. Evidence and implications of recent climate change in northern Alaska and other arctic regions. Climatic Change 72:251-298. https://doi.org/10.1007/s10584-005-5352-2

Holen, D., S. M. Hazell, and D. S. Koster. 2012. Subsistence harvests and uses of wild resources by communities in the eastern interior of Alaska, 2011. Technical paper number 372. Department of Fish and Game, Division of Subsistence, Juneau, Alaska, USA. [online] URL: https://www.arlis.org/docs/voll/ AlaskaGas/Article/Article ADFGSubsistence 2012 SubsistHarvestsUsesWild.pdf 
Hudson, H. E. 2015. After broadband: a study of organizational use of broadband in southwest Alaska. University of Alaska Anchorage, Institite of Social and Economic Research, Anchorage, Alaska, USA. [online] URL: https://scholarworks. alaska.edu/handle/11122/5959

Huntington, H. P., S. Fox, F. Berkes, and I. Krupnik. 2005. The changing Arctic: Indigenous perspectives. Pages 61-98 in Arctic Monitoring and Assessment Programmme, editors. Arctic climate impact assessment. Cambridge University Press, Cambridge, UK.

Huntington, H. P., L. T. Quakenbush, and M. Nelson. 2017. Evaluating the effects of climate change on Indigenous marine mammal hunting in northern and western Alaska using traditional knowledge. Frontiers in Marine Science 4:17. https:// doi.org/10.3389/fmars.2017.00319

Huskey, L., M. Berman, and A. Hill. 2004. Leaving home, returning home: migration as a labor market choice for Alaska Natives. Annals of Regional Science 38(1):75-92. https://doi. org/10.1007/s00168-003-0141-1

Intergovernmental Panel on Climate Change (IPCC). 2014. Climate change 2014: impacts, adaptation and vulnerability: Part A, global and sectoral aspects. Working Group II Contribution to the IPCC Fifth Assessment Report. Cambridge University Press, Cambridge, UK. https://doi.org/10.1017/CBO9781107415379

Intergovernmental Panel on Climate Change (IPCC). 2019. IPCC special report on the ocean and cryosphere in a changing climate. IPCC, Geneva, Switzerland. [online] URL: https://www.ipcc.ch/ $\underline{\text { srocel }}$

Inuit Circumpolar Council (ICC). 2015. Alaskan Inuit food security conceptual framework: how to assess the arctic from and Inuit perspective. Technical report. ICC, Alaska, Anchorage, Alaska, USA. [online] URL: https://iccalaska.org/wp-icc/wpcontent/uploads/2016/03/Food-Security-Summary-and-RecommendationsReport.pdf

Johnson, N., C. Behe, F. Danielsen, E. Krummel, S. Nickels, and P. L. Pulsifer. 2016. Community-based monitoring and Indigenous knowledge in a changing Arctic: a review for the Sustaining Arctic Observing Networks. University of Colorado, Boulder, Colorado, USA. [online] URL: https://secureservercdn. net/104.238.71.250/hh3.0e7.myftpupload.com/wp-content/ uploads $/ 2019 / 01 / \mathrm{cbm}$ report final.pdf

Kaden, U., P. P. Patterson, J. Healy, A. Healy, and L. Barbars. 2016. Stemming the revolving door: teacher retention and attrition in Arctic Alaska schools. Global Education Review 3 (1):129-147. [online] URL: https://files.eric.ed.gov/fulltext/ EJ1090201.pdf

Kraegel, L. 2019. After fears of closure, Atka's school is back to 10 students and staying open. Alaska Public Media, Unalaska, Alaska, USA. [online] URL: https://www.alaskapublic. org/2019/09/18/after-fears-of-closure-atkas-school-is-back-to-10students-and-staying-open/

Larsen, J. N., and G. Fondahl, editors. 2014. Arctic Human Development Report. Nordic Council of Ministers, Copenhagen, Denmark. [online] URL: http://norden.diva-portal.org/smash/ get/diva2:788965/FULLTEXT03.pdf
Loeffler, B. 2015. Mining and sustainable communities: a case study of the Red Dog Mine. Economic Development Journal 14 (2):23-31. [online] URL: http://hdl.handle.net/11122/9571

Loring, P. A., and S. C. Gerlach. 2015. Searching for progress on food security in the North American North: a research synthesis and meta-analysis of the peer-reviewed literature. Arctic 68 (3):380-392. https://doi.org/10.14430/arctic4509

Louv, R. 2008. Last child in the woods: saving our children from nature-deficit disorder. Updated and expanded edition. Algonquin Books, Chapel Hill, North Carolina, USA.

Magdanz, J., N. S. Braem, B. C. Robbins, and D. S. Koster. 2010. Subsistence harvests in northwest Alaska, Kivalina and Noatak, 2007. Technical paper number 354. Alaska Department of Fish and Game, Division of Subsistence, Kotzebue, Alaska, USA. [online] URL: http://www.adfg.alaska.gov/techpap/tp354.pdf

Martin, S. 2009. The effects of female out-migration on Alaska villages. Polar Geography 32:61-67. https://doi.org/10.1080/108$\underline{89370903000455}$

McKeown, B., and D. B. Thomas. 2013. Q methodology. Quantitative applications in the social sciences series. Volume 66. Sage, Los Angeles, California, USA.

Moerlein, K. J., and C. Carothers. 2012. Total environment of change: impacts of climate change and social transitions on subsistence fisheries in northwest Alaska. Ecology and Society 17(1):10. https://doi.org/10.5751/ES-04543-170110

Mosites, E., S. Seeman, A. Fenaughty, K. Fink, L. Eichelberger, P. Holck, T. K. Thomas, M. G. Bruce, and T. W. Hennessy. 2020. Lack of in-home piped water and reported consumption of sugarsweetened beverages among adults in rural Alaska. Public Health Nutrition 23(5):861-868. https://doi.org/10.1017/S1368980019002477

Mueller, R. P., R. S. Brown, H. Hop, and L. Moulton. 2006. Video and acoustic camera techniques for studying fish under ice: a review and comparison. Reviews in Fish Biology and Fisheries 16: 213-226. https://doi.org/10.1007/s11160-006-9011-0

Nicosia, M. 2019. Alaska schools pay a price for the nations' slowest internet, but change is coming. Hechinger Report, 28 January. [online] URL: https://hechingerreport.org/alaskaschools-pay-a-price-for-the-nations-slowest-internet-but-changeis-coming/

Oceana and Kawerak. 2014. Bering Strait marine life and subsistence data synthesis. Oceana and Kawerak, Nome, Alaska, USA. [online] URL: https://oceana.org/publications/reports/thebering-strait-marine-life-and-subsistence-data-synthesis

O’Keefe, K., S. Gearheard, G. Aipellee, A. Apak, J. Enuaraq, D. Iqaqrialu, L. Palloq, J. Panipak, A. Sivugat, D. Chiu, B. Culling, S. Lam, J. Lau, A. Levson, T. Mosstajiri, J. Park, T. Phillips, M. Brand, R. Enns, and E. Wingate. 2009. On the trails of the Inuit. Inside GNSS magazine, March/April. [online] URL: https://www. nabohome.org/meetings/glthec/materials/gearhead/IgliniitGNSSmagazine. pdf

Oneworld Classrooms. 2007. OneWorld Classrooms Arctic classroom travel resources. OneWorld Classrooms, Andover, Massachusetts, USA. [online] URL: http://www.ccproject.org/ travel/arctic/index.html 
Panikkar, B., and B. Lemmond. 2020. Being on land and sea in troubled times: climate change and food sovereignty in Nunavut. Land 9(12):508. https://doi.org/10.3390/land9120508

Panikkar, B., B. Lemmond, B. Else, and M. Murray. 2018. Ice over troubled waters: navigating the Northwest Passage using Inuit knowledge and scientific information. Climate Research 75:81-94. https://doi.org/10.31230/osf.io/bzywv

Pearce, T., B. Smit, F. Duerden, J. D. Ford, A. Goose, and F. Kataoyak. 2010. Inuit vulnerability and adaptive capacity to climate change in Ulukhaktok, Northwest Territories, Canada. Polar Record 46:157-177. https://doi.org/10.1017/S0032247409008602

Pearce, T., H. Wright, R. Notaina, A. Kudlak, B. Smit, J. D. Ford, and C. Furgal. 2011. Transmission of environmental knowledge and land skills among Inuit men in Ulukhaktok, Northwest Territories, Canada. Human Ecology 39:271-288. https://doi. org/10.1007/s10745-011-9403-1

Perera, D., J. Agnihotri, O. Seidou, and R. Djalante. 2020. Identifying societal challenges in flood early warning systems. International Journal of Disaster Risk Reduction 51:9. https:// doi.org/10.1016/j.ijdrr.2020.101794

Prichard, A. K., G. C. Carroll, J. C. George, S. M. Murphy, M. D. Smith, R. S. Suydam, and D. Yokel. 2001. Use of satellite telemetry data, GIS, and HTML to create an interactive display of caribou movements. Rangifer 23(5):101-102 https://doi. org/10.7557/2.23.5.1688

Raymond-Yakoubian, J., Y. Khokhlov, and A. Yarzutkina. 2014. Indigenous knowledge and use of Bering Strait Region ocean currents. Final report. Social Science Program, National Park Service shared Beringian Heritage Program. Kawerak, Nome, Alaska, USA. [online] URL: https://kawerak.org/wp-content/ uploads/2018/04/OC-report-for-web.pdf

Rodon, T., and Lévesque. 2018. Education in Nunavut. Pages 251-267 in T. Bell and T. M. Brown, editors. From science to policy in the eastern Canadian Arctic: an integrated regional impact study (IRIS) of climate change and modernization. ArcticNet, Quebec City, Quebec, Canada.

Schmidt, J. I. 2015. TUNDRA project final report. \#S192040/ S30. The Norwegian Research Council. University of Alaska Anchorage, Institute of Social and Economic Research, Anchorage, Alaska, USA. [online] URL: https://pubs.iseralaska. org/media/9de5e8b9-97b3-4d6e-bfc4-c21a2cca40da/

TUNDRA final report.pdf

Schmidt, J. I., D. A. Clark, N. Lokken, J. Lankshear, and V. Hausner. 2018. The role of trust in sustainable management of land, fish, and wildlife populations in the Arctic. Sustainability 10:3124. https://doi.org/10.3390/su10093124

Schneider, W., K. Brewster, K. Kielland, and C. Jones. 2013. Project jukebox: unsafe ice. University of Alaska Fairbanks, Digital branch of the UAF Oral History Program, Fairbanks, Alaska, USA. [online] URL: http://jukebox.uaf.edu/site7/thingsthemes/unsafe-ice

Schroeder, R. F., D. B. Andersen, R. Bosworth, J. M. Morris, and J. M. Writh. 1987. Subsistence in Alaska: arctic, interior, southcentral, southwest, and western regional summaries.
Technical Paper No. 150. Alaska Department of Fish and Game, Division of Subsistence, Juneau, Alaska, USA.

Schweitzer, P. P., R. Barnhardt, and L. M. Kaplan. 2015. Inuit regions of Alaska. Pages 105-150 in J. N. Larsen, P. Schweitzer, and A. N. Petrov, editors. Arctic social indicators II. Nordic Council of Ministers, Copenhagen, Denmark. [online] URL: http://norden.diva-portal.org/smash/get/diva2:789051/FULLTEXT02. pdf

Slobodin, R. 1962. Band organization of the Peel River Kutchin. Bulletin National Museum of Canada 179:1-97.

Sullivan, K. 2016. More families move toward in-home education. Peninsula Clarion, 17 January. [online] URL: https://www. peninsulaclarion.com/news/2016-01-17/more-families-move-towardin-home-education/?quicktabs $1=0$

Thomas, T. K., T. Ritter, D. Bruden, M. Bruce, K. Byrd, R. Goldberger, J. Dobson, K. Hickel, J. Smith, and T. Hennessy. 2016. Impact of providing in-home water service on the rates of infectious diseases: results from four communities in Western Alaska. Journal of Water and Health 14(1):132-141. https://doi. org/10.2166/wh.2015.110

Towne, S. D., M. L. Smith, and M. G. Ory. 2014. Geographic variations in access and utilization of cancer screening services: examining disparities among American Indian and Alaska Native Elders. International Journal of Health Geographics 13:11. https://doi.org/10.1186/1476-072X-13-18

Tremblay, M. 2018. Traveling and hunting. Pages 305-322 in T. Bell and T. M. Brown, editors. From science to policy in the eastern Canadian Arctic: an integrated regional impact study (IRIS) of climate change and modernization. ArcticNet, Quebec City, Quebec, Canada.

Upper One Games. 2016. Never alone. Upper One Games and ELine Media, Anchorage, Alaska, USA. [online] URL: http:// neveralonegame.com/

Voice of the Arctic Iñupiat and Iñupiat Community of the Arctic Slope (ICAS). 2021. Arctic broadband initiative: broadband workshop. Interim Report. ICAS, Utqiagvik, Alaska, USA. [online] URL: https://voiceofthearcticinupiat.org/wp-content/ uploads/2021/03/Arctic-Broadband-Initiative-Workshop-Report. pdf

Walsh, J. E., T. J. Ballinger, E. S. Euskirchen, E. Hanna, J. Mård, J. E. Overland, H. Tangen, and T. Vihma. 2020. Extreme weather and climate events in northern areas: a review. Earth-Science Reviews 209:103324. https://doi.org/10.1016/j.earscirev.2020.103324

Watts, S., and P. Stenner. 2012. Doing Q methodological research: theory, method and interpretation. Sage, Los Angeles, California, USA.

Wiggins, H. V., and B. Turner-Bogren. 2020. Sea Ice Prediction Network-Phase 2 (SIPN2). Conference poster. American Geophysical Union Fall Meeting, virtual conference. [online] URL: https://www.arcus.org/files/page/documents/28191/ agu2020 sipn 2 poster.pdf

Wolfe, R. J. 2004. Local traditions and subsistence: a synopsis from twenty-five years of research by the state of Alaska. 
Technical paper number 284. Alaska Department of Fish and Game, Division of Subsistence, Juneau, Alaska, USA. [online] URL: https://www.adfg.alaska.gov/techpap/tp284.pdf

Yardley, W. 2009. Alaska's rural schools fight off extinction. New York Times, 25 November. [online] URL: https://www.nytimes. com/2009/11/26/us/26alaska.html

Zabala, A. 2014. Qmethod: a package to explore human perspectives using Q methodology. The R Journal 6(2):163-173. https://doi.org/10.32614/rj-2014-032

Zabala, A. and U. Pascual. 2016. Bootstrapping Q methodology to improve the understanding of human perspectives. PLoS ONE 11(2):e0148087. https://doi.org/10.1371/journal.pone.0148087

Zabala, A., C. Sandbrook, and N. Mukherjee. 2018. When and how to use $\mathrm{Q}$ methodology to understand perspectives in conservation research. Conservation Biology 32:1185-1194. https://doi.org/10.1111/cobi.13123 
Appendix 1. Interview guide used during interviews in Noorvik, Noatak, and Brevig Mission in March 2017.

1) I am going to go through some technologies and ask you if you own any and use them for subsistence. If you do own, did you lend it out and if you do not own, did you borrow? Finally, what year did you start using the technology.

\begin{tabular}{|c|c|c|c|c|c|}
\hline Technology & $\begin{array}{l}\text { How } \\
\text { many } \\
\text { own } \\
(\#) ?\end{array}$ & $\begin{array}{l}\text { Used for } \\
\text { subsistence? }\end{array}$ & $\begin{array}{l}\text { Did you lend to } \\
\text { someone outside } \\
\text { your HH (\# of } \\
\text { times)? }\end{array}$ & $\begin{array}{l}\text { Did you } \\
\text { borrow for } \\
\text { subsistence (\# } \\
\text { of times )? }\end{array}$ & $\begin{array}{l}\text { What year } \\
\text { did you } \\
\text { start using } \\
\text { the tech.? }\end{array}$ \\
\hline Jet boat & & Y N & Y N \# & $\mathrm{Y} \mathrm{N} \#$ & \\
\hline Prop boat & & Y N & Y N\# & Y N \# & \\
\hline Snowmachine & & $\mathrm{YN}$ & $\mathrm{YN} \#$ & $\mathrm{YN}_{-}$ & \\
\hline ATV & & Y N & Y N \# & Y N\# & \\
\hline Car or Truck & & Y N & Y N \# & Y N \# & \\
\hline Airplane & & Y N & Y N \# & Y N \# & \\
\hline Dogsled & & Y N & Y N \# & Y N \# & \\
\hline GPS & & $\mathrm{YN}$ & $\mathrm{YN} \#$ & $\mathrm{YN}_{-}$ & \\
\hline Cell phone & & $\mathrm{YN}$ & $\mathrm{YN}$ & $\mathrm{YN}_{-}$ & \\
\hline Computer (prog./internet) & & Y N & $\mathrm{YN} \#$ & $\mathrm{YN} \#$ & \\
\hline Electronic range finder & & $\mathrm{YN}$ & $\mathrm{YN}$ & $\mathrm{YN}_{-}$ & \\
\hline Chainsaw & & $\mathrm{YN}$ & $\mathrm{YN} \#$ & $\mathrm{YN}_{-}$ & \\
\hline Ice auger & & $\mathrm{YN}$ & $\mathrm{YN} \#$ & $\mathrm{Y} \mathrm{N} \#$ & \\
\hline Electric smoker & & $\mathrm{YN}$ & $\mathrm{YN} \#$ & $\mathrm{YN} \#$ & \\
\hline Generator(s) in camp & & $\mathrm{YN}$ & $\mathrm{YN} \#$ & Y N \# & \\
\hline Satellite phone & & Y N & Y N \# & Y N\# & \\
\hline SPOT (Personal Locator) & & $\mathrm{YN}$ & Y N\# & Y N\# & \\
\hline
\end{tabular}




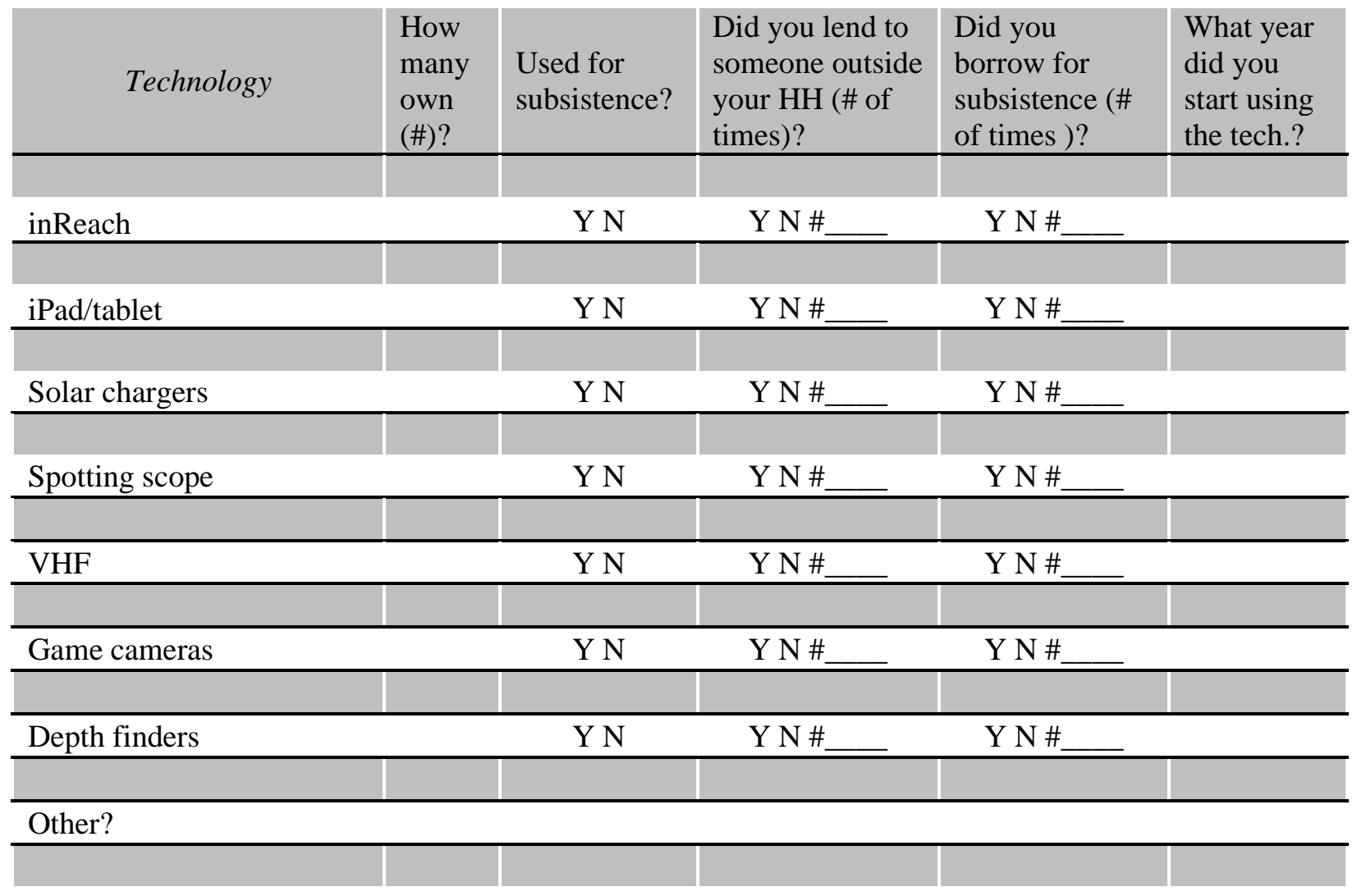

2) Are there any other technologies you use for subsistence I have not mentioned such as websites such as Facebook, phone apps like NOAA weather, google maps, backcountry navigator, etc.?

3) Are there any technologies that you don't have now, but would like to own that would help you get subsistence resources?

4) Do you typically have cell service in the areas you hunt or fish? Yes No If yes, what kind (circle all that apply) $4 \mathrm{G} \quad 3 \mathrm{G} \quad$ LTE $\quad$ Most common?

5) Does cell coverage influence where you travel or go hunting, fishing, or camping? Yes No Why?

6) In the last 10 years have you attempted to harvest....?

\begin{tabular}{|c|c|c|}
\hline Resource & Attempt & Harvest \\
\hline Moose & Y N & Y N \\
\hline Caribou & Y N & Y N \\
\hline Seal & $\mathrm{YN}$ & $\mathrm{YN}$ \\
\hline
\end{tabular}




\begin{tabular}{|c|c|c|}
\hline Whale & Y N & Y N \\
\hline Non-salmon (i.e. Whitefish, Burbot, Sheefish) & $\mathrm{YN}$ & Y N \\
\hline Salmon & Y N & Y N \\
\hline Furbearers & $\mathrm{YN}$ & $\mathrm{YN}$ \\
\hline Waterfowl & Y N & $\mathrm{YN}$ \\
\hline Bears & Y N & YN \\
\hline Wolves & $\mathrm{YN}$ & $\mathrm{YN}$ \\
\hline & Y N & YN \\
\hline
\end{tabular}

7) In the last 10 years, how has technology changed the way you hunt the resources listed above?

8) Is there a species in particular that technology has really helped to improve your ability to harvest? For example, Facebook helps us know when to go out and get caribou.

9) In the last 10 years have you made any switches among technologies to get subsistence foods rather than upgrades to hunt? For example, running ATVs along rivers to hunt moose instead of boats to save gas or switching from a liquid cooled snowmachine to fan cooled.

10) Have you made any upgrades in the last 10 years to the technology you use to do subsistence? If so for what resource and why? What year did you make the upgrade?

11) Are there any downside to using technology to do subsistence? For example, does it make you more vulnerable to getting lost or I have to carry more batteries/weight?

Yes No Why or why not?

12) In the last 10 years, to what extent have fuel prices changed the distances you travel to hunt or fish?

Not at all Decrease Increase

If decreased or increased, do you go...

$25 \%$ more/less further $\quad 50 \%$ more/less further $\quad 75 \%$ more/less further Twice as far

13) In the last 10 years, what extent have fuel prices changed how often you hunt or fish?

Not at all Decrease Increase 
If decreased or increased, do you go...

$25 \%$ more/less often $\quad 50 \%$ more/less often $\quad 75 \%$ more/less often Twice as much

14) Are you using technology to help deal with the following environmental changes....

\begin{tabular}{l|c|}
\multicolumn{1}{c|}{ Issues } & \\
\hline Dangerous ice & Y N \\
\hline Poor river/lake navigability & Y N \\
\hline Erosion & Y N \\
\hline Extreme weather (i.e. storms) & Y N \\
\hline Less snow & Y N \\
\hline More shrubs & Y N \\
\hline & \\
\hline Others(?) & \\
\hline
\end{tabular}

Please explain how you are using technology to overcome these issues.

15) Do you think technology can help you overcome problems raised by climate change during hunting and fishing? Yes No Don't know

\section{ACCESS/DISTRIBUTION/ABUNDANCE/SAFETY}

16) I will go through a list of statements and please answer yes or no. Has technology ....

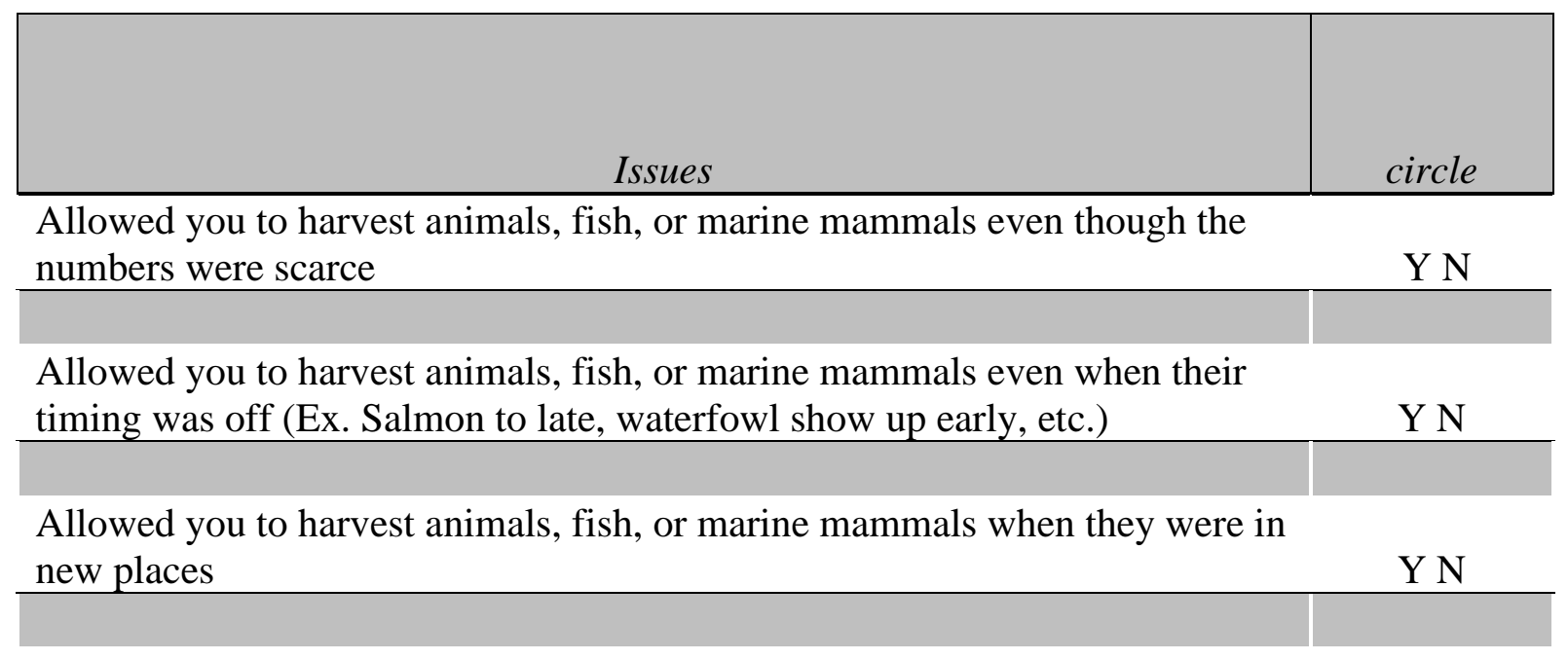


Allowed you to do multi-purpose trips so you go after multiple subsistence resources at one time

Allowed you to access areas where the water was previously too shallow too far from the community

Y N

Allowed you to communicate more with your hunting/fishing partner(s)

Y N

Helped you overcome management restrictions such as short harvest season, bulls only

Y N

Helped you locate animals or fish more easily BEFORE you head out on the land/water

Helped you locate animals or fish more easily AFTER you head out on the land/water

Allowed you to travel over terrain or water that before was not navigable

Created crowding issues among hunters/fisherman (i.e. increased competition)

Others?

\section{SUBSISTENCE and CULTURE}

17) I will go through another list of statements and please answer yes or no. Has technology ....

\begin{tabular}{|l|c|}
\hline SUBSISTENCE CULTURE & \\
\hline \multicolumn{1}{|c|}{ Issue } & \\
\hline Allowed me to try new subsistence activities & circle \\
\hline & \\
\hline Allowed me to take more risks while out on the land/water & Y N \\
\hline & \\
\hline Allowed me to out more often & Y N \\
\hline
\end{tabular}




\begin{tabular}{|l|c|}
\hline Allowed me to make more overnight trips & Y N \\
\hline Allowed me to squeeze subsistence trips in between work or other commitments & Y N \\
\hline Allowed me to take children or youth out more often to do subsistence & Y N \\
\hline Allowed me to hunt or fish more often by myself (i.e. alone)? & Y N \\
\hline Allowed me to be more successful in general & Y N \\
\hline & \\
\hline Cause me to share costs more often with friends or relatives & Y N \\
\hline & \\
\hline Allowed me to share more subsistence foods & Y N \\
\hline & \\
\hline Decreased the chance I will be stranded & Y N \\
\hline & \\
\hline Increased my ability to make it back to the community safely & Y N \\
\hline & Y N \\
\hline Rely less on what elders have taught me & \\
\hline
\end{tabular}

18) Has technology changed what you need to know from elders? For example, it may no longer be important to read stars. Yes No Explain

19) What are the things that are still important to know

20) Has technology changed how you learn how to fish or hunt?

21) Is there any specific changes in the climate or environment, like low snow, lack of river ice, lower river levels that technology has really helped you overcome?

22) During subsistence do you think technology engages people more with each other? How about the land? How about local knowledge?

23) What are the 3 most important issues for the community right now?

24) Is technology being used to address these issues? Yes No

Please explain why or why not?

25) Overall has technology positively or negatively influenced the community? How? Circle Positive Negative

26) Are there any technologies your community needs to help meet future challenges? Please list the challenges and how technology can help.

Are there any other comments you would like to make on technology before we close? 
Appendix 2. The 25 statements used during q-sort exercises with individuals from Noorvik ( $\mathrm{n}=$ 7), Noatak ( $\mathrm{n}=6$ ), and Brevig Mission $(\mathrm{n}=9)$ in March 2017. Scores ranged from strongly agree (4) to neutral (0) to strongly disagree (-4). \# indicates statement number.

\begin{tabular}{|c|c|c|}
\hline \# & Statement & Median \\
\hline 9 & Without subsistence rights this community would not survive & 3 \\
\hline 11 & Technology has helped our children get a better education & 2 \\
\hline 18 & Limited access to money is a big reason why people do not do subsistence & \\
\hline 12 & Jobs keeps this community alive & 1 \\
\hline 13 & Technology has had a positive experience in our community & 1 \\
\hline 1 & Technology helps increase communication among people in the community & \\
\hline 2 & $\begin{array}{l}\text { People of this community use technology to have more of a say in resource } \\
\text { management }\end{array}$ & \\
\hline 4 & The community has kept up with changes in technology & 0 \\
\hline 6 & $\begin{array}{l}\text { The need for technology makes it hard for youth to get started doing } \\
\text { subsistence }\end{array}$ & \\
\hline 7 & $\begin{array}{l}\text { Technology can be used to address social issues like alcohol or drug use, } \\
\text { poor education, low employment }\end{array}$ & \\
\hline 10 & Technology will be able to help us deal with climate change & \\
\hline 14 & Our youth are very active in subsistence practices & \\
\hline 15 & Climate change is not a threat to our community & \\
\hline 19 & $\begin{array}{l}\text { Contaminants are the biggest concern in our subsistence resources and need } \\
\text { to be tested }\end{array}$ & \\
\hline 20 & The children in our community are learning enough about subsistence & \\
\hline 21 & Technology has helped the community get more subsistence foods & \\
\hline 23 & People in the community do more subsistence now because of technology & 0 \\
\hline 24 & $\begin{array}{l}\text { Technology gives people from outside of our community more of an } \\
\text { advantage to get subsistence foods }\end{array}$ & \\
\hline 25 & $\begin{array}{l}\text { The benefits from technology outweigh the negatives like needing to pay for } \\
\text { gas, maintain equipment, etc. }\end{array}$ & \\
\hline 3 & The economy is a not bigger issue for our community than climate change & -1 \\
\hline 5 & $\begin{array}{l}\text { Technology will be not be important in solving future challenges the } \\
\text { community may face }\end{array}$ & -1 \\
\hline 8 & $\begin{array}{l}\text { Our community is more isolated from other communities because of } \\
\text { technology }\end{array}$ & \\
\hline 16 & People depend on technology too much when doing subsistence & -1 \\
\hline 17 & The changing climate is negatively affecting subsistence resources & -1 \\
\hline 22 & Children need to know less from elders because of technology & -3 \\
\hline
\end{tabular}


Appendix 3. Q-statements used along with the themes captured by each statement and their attitude towards technology (Positive (pos.) or negative (neg.)). Z-scores are the weighted average of the values for each statement and indicate the agreement between statements and factors. Distinction and consensus indicate whether the statements were distinct to a factor(s), had consensus, or were not assigned. Comparisons assess the significance of the differences between $\mathrm{z}$-scores $(* *$ indicates $\mathrm{p}=0.01$, $*$ indicates $\mathrm{p}=0.05$ ).

\begin{tabular}{|c|c|c|c|c|c|c|c|c|c|c|c|c|c|}
\hline \multirow[b]{2}{*}{$\begin{array}{l}\text { State- } \\
\text { ment } \\
\#\end{array}$} & \multirow[b]{2}{*}{ Main theme } & \multicolumn{5}{|c|}{ Factor z-score } & \multirow[b]{2}{*}{$\begin{array}{l}\text { Distinction } \\
\text { and } \\
\text { consensus }\end{array}$} & \multicolumn{6}{|c|}{ Distinction comparisons } \\
\hline & & $\begin{array}{l}\text { Role of } \\
\text { tech- } \\
\text { nology }\end{array}$ & 1 & 2 & 3 & 4 & & $\begin{array}{c}\mathrm{F} 1 \\
\mathrm{~F} 2\end{array}$ & $\begin{array}{c}\mathrm{F} 1 \\
\mathrm{~F} 3\end{array}$ & $\begin{array}{c}\mathrm{F} 1 \\
\mathrm{~F} 4\end{array}$ & $\begin{array}{c}\mathrm{F} 2 \\
\mathrm{~F} 3\end{array}$ & $\begin{array}{c}\mathrm{F} 2 \\
\mathrm{~F} 4\end{array}$ & $\begin{array}{r}\mathrm{F} 3 \\
\mathrm{~F} 4 \\
\end{array}$ \\
\hline 10 & Climate & Pos. & 0.205 & -0.092 & 0.281 & -1.500 & Dist. F4 only & & & $* *$ & & $* *$ & $* *$ \\
\hline 3 & Climate & NA & -0.858 & -0.515 & -1.091 & 0.031 & & & & $* *$ & & & $* *$ \\
\hline 15 & Climate & NA & -0.544 & -0.068 & -0.225 & 1.300 & Dist. F4 only & & & $* *$ & & $* *$ & $* *$ \\
\hline 11 & Education & Pos. & 1.172 & 1.652 & 0.510 & -0.910 & Dist. F3, F4 & & $*$ & $* *$ & $* *$ & $* *$ & $* *$ \\
\hline 22 & Education & $\mathrm{NA}$ & -1.590 & -1.854 & -2.488 & -0.900 & Dist. F3, F4 & & $* *$ & $*$ & $*$ & $* *$ & $* *$ \\
\hline 25 & Money/Jobs & Pos. & -0.340 & -0.829 & 0.327 & 0.350 & & & $*$ & $*$ & $* *$ & $* *$ & \\
\hline 12 & Money/Jobs & NA & 1.884 & 1.151 & 0.584 & -1.400 & Dist. F1, F4 & $* *$ & $* *$ & $* *$ & & $* *$ & $* *$ \\
\hline 17 & Money/Jobs & NA & 1.118 & -1.478 & -0.309 & 0.500 & Dist. F2, F3 & $* *$ & $* *$ & & $* *$ & $* *$ & $*$ \\
\hline 18 & Money/Jobs & NA & 0.004 & 1.521 & 1.446 & 0.490 & & $* *$ & $* *$ & & & $* *$ & $* *$ \\
\hline 1 & Social & Pos. & 0.613 & 0.342 & 0.870 & -0.560 & Dist. F4 only & & & $* *$ & & $* *$ & $* *$ \\
\hline 2 & Social & Pos. & 0.724 & -0.113 & -0.943 & 0.500 & Dist. F3 & $* *$ & $* *$ & & $* *$ & & $* *$ \\
\hline 7 & Social & Pos. & 0.953 & -0.471 & 0.211 & 0.700 & Dist. F2 & $* *$ & $*$ & & $*$ & $* *$ & \\
\hline 6 & Subsistence & Neg & -0.152 & -0.054 & 1.794 & -0.150 & Dist. F3 only & & $* *$ & & $* *$ & & $* *$ \\
\hline 16 & Subsistence & Neg & -1.216 & -0.309 & -0.877 & -0.052 & & $* *$ & & $* *$ & & & $*$ \\
\hline 24 & Subsistence & $\mathrm{Neg}$ & -0.234 & 0.050 & 0.184 & 0.000 & Consensus & & & & & & \\
\hline 21 & Subsistence & Pos. & -1.639 & 1.525 & -0.553 & -0.140 & Dist. F1, F2 & $* *$ & $* *$ & $* *$ & $* *$ & $* *$ & \\
\hline 23 & Subsistence & Pos. & -0.682 & 1.244 & -1.700 & 0.260 & Dist. all & $* *$ & $* *$ & $* *$ & $* *$ & $* *$ & $* *$ \\
\hline
\end{tabular}




\begin{tabular}{|c|c|c|c|c|c|c|c|c|c|c|c|c|c|}
\hline \multirow[b]{2}{*}{$\begin{array}{l}\text { State- } \\
\text { ment } \\
\#\end{array}$} & \multicolumn{6}{|c|}{ Factor z-score } & \multirow[b]{2}{*}{$\begin{array}{l}\text { Distinction } \\
\text { and } \\
\text { consensus }\end{array}$} & \multicolumn{6}{|c|}{ Distinction comparisons } \\
\hline & Main theme & $\begin{array}{l}\text { Role of } \\
\text { tech- } \\
\text { nology }\end{array}$ & 1 & 2 & 3 & 4 & & $\begin{array}{c}\mathrm{F} 1 \\
\mathrm{~F} 2\end{array}$ & $\begin{array}{c}\mathrm{F} 1 \\
\mathrm{~F} 3\end{array}$ & $\begin{array}{r}\mathrm{F} 1 \\
\mathrm{~F} 4\end{array}$ & $\begin{array}{c}\mathrm{F} 2 \\
\mathrm{~F} 3\end{array}$ & $\begin{array}{c}\mathrm{F} 2 \\
\mathrm{~F} 4\end{array}$ & $\begin{array}{c}\mathrm{F} 3 \\
\mathrm{~F} 4\end{array}$ \\
\hline 9 & Subsistence & NA & 1.679 & 1.682 & 1.678 & 2.400 & & & & $*$ & & $*$ & \\
\hline 14 & Subsistence & NA & -0.227 & -0.326 & 0.708 & -2.100 & Dist. F3, F4 & & $* *$ & $* *$ & $* *$ & $* *$ & $* *$ \\
\hline 19 & Subsistence & NA & 0.768 & -1.073 & 0.158 & 1.900 & Dist. F2, F4 & $* *$ & & $* *$ & $* *$ & $* *$ & $* *$ \\
\hline 20 & Subsistence & NA & -1.605 & -0.530 & -0.002 & 0.094 & Dist. F1 only & $* *$ & $* *$ & $* *$ & & & \\
\hline 8 & $\begin{array}{l}\text { Technology } \\
\text { general } \\
\text { Technology }\end{array}$ & Neg. & -0.699 & -0.550 & 0.690 & -0.520 & Dist. F3 only & & $* *$ & & $* *$ & & $* *$ \\
\hline 4 & general & Pos. & 0.313 & -0.413 & -0.384 & -0.780 & Dist. F1 only & $* *$ & $*$ & $* *$ & & & \\
\hline 5 & $\begin{array}{l}\text { Technology } \\
\text { general } \\
\text { Technology }\end{array}$ & Pos. & -0.498 & -1.182 & -0.018 & 0.041 & Dist. F2 only & $*$ & & & $* *$ & $* *$ & \\
\hline 13 & general & Pos. & 0.851 & 0.689 & -0.852 & 0.520 & Dist. F3 only & & $* *$ & & $* *$ & & $* *$ \\
\hline
\end{tabular}

